\title{
The Impacts of Industry 4.0 on Marketing Activities and Strategies of Iron and Steel Industry in Developing Countries: Case for Uganda
}

\author{
Alfred Ocheng Komakech', Jiaguo Liu ${ }^{1}$, Alfred Omo², Emmanuel Afanga Archelaus Basua ${ }^{3}$ \\ ${ }^{1}$ School of Economic and Management, China University of Geosciences, Wuhan, China \\ ${ }^{2}$ Faculty of Medicine, Mbarara University of Science and Technology, Mbarara, Uganda \\ ${ }^{3}$ School of Earth Sciences, China University of Geosciences, Wuhan, China \\ Email: kalfredocheng@gmail.com, ‘jiaguoliu@cug.edu.cn, alfredomo@ymail.com, basfanga@yahoo.com
}

How to cite this paper: Komakech, A. O., Liu, J. G., Omo, A., \& Basua, E. A. A. (2021). The Impacts of Industry 4.0 on Marketing Activities and Strategies of Iron and Steel Industry in Developing Countries: Case for Uganda. Open Journal of Social Sciences, 9, 591-626.

https://doi.org/10.4236/jss.2021.95034

Received: April 23, 2021

Accepted: May 23, 2021

Published: May 26, 2021

Copyright $\odot 2021$ by author(s) and Scientific Research Publishing Inc. This work is licensed under the Creative Commons Attribution International License (CC BY 4.0).

http://creativecommons.org/licenses/by/4.0/

(c) (i) Open Access

\begin{abstract}
The iron and steel industry is one of the main contributors to the total Gross Domestic Product (GDP) of most developing countries in Africa and is key for both domestic and global markets. The holistic approach to Industry 4.0 needs a wider look at the transition taking place in the area of marketing. The paper aims at investigating the impacts of Industry 4.0 on marketing activities and strategies of iron and steel companies in developing countries by identifying which consideration factors are relevant when adopting industry 4.0 in relation to the cost of doing business, then propose strategies and possible solutions that could be considered. A research by survey method through distributes descriptive and deductive approach to collect primary data in questionnaire format. The results show statistical evidence to explain impact of industry 4.0 on marketing activities and strategies such as; effects of rapidly evolving technological capabilities, product quality, quantity, and raw material, increased supply chain and channel strategy, value addition, organizational realignments to integrate physical and digital technologies, positioning in the market, pipeline management, illicit trade practices, skills gap, research and innovation, website foundation, technology stack, content strategy, lead generation, pipeline management, and data analysis (analytic tools). Steel companies should adopt new technologies to improve productivity and standardization, and call for enhancement of regulatory mechanisms to remove incentives for illicit trade practices such as tax evasion, falsification and substandard products.
\end{abstract}




\section{Keywords}

Uganda Steel Industry, Industry 4.0, Marketing Strategy and Activities, Technological Development, Marketing Mix, Internet Technology

\section{Introduction}

In today's world, the current rapid changes in industrial production methods and the business environment of manufacturing companies are driven by global demand and competition. The current industrial transformation is known as the fourth industrial revolution "Industry 4.0" which some commentators also refer to as the internet of things (IoT) is on the basis of cyber-physical production systems (CPPS), merging of real and virtual worlds, was developed based on the past experiences (Toro et al. 2015; Drath and Horch, 2014: p. 56) to links people, and all smart factory components to communicate with each other. According to (Lasi et al., 2014: p. 239), the first industrial revolution "Industry 1.0" emerged in the $18^{\text {th }}$ century when the concept of streamlining production began with mechanical production driven by steam and water power; the second industrial revolution "Industry 2.0" concept was based on introduction of mass production in early $20^{\text {th }}$ century driven by electricity development (Baygin et al., 2016: p. 1); and the third industrial revolution "Industry 3.0" concept that emerged in 1970s, was based on introduction of automation of production processes by development of computer and information technology (IT) (Drath and Horch, 2014: p. 56). Therefore, the industry 4.0 concept, is based on both technological and business aspects. That is, digital transformation of business models, value chain, products, and services Hermann, Pentek, and Otto (2016).

Technology developments have not only impacted on the production capacity of firms but also market coverage, and consumers' everyday lives. It has become a crucial aspect of business strategic planning (İnal, 2009: p. 108), The developed countries represent a good example of a growing information society driven by technology Reichheld and Sasser (1990) and Volker (2005). For a company, "information is the most precious of modern corporate resources and its exploitation is the key to competitive survival, the spotlight falls on marketing". Companies depend on technology to tack up, handle, analyse and interpret the high amount of information (Fleisher, 2008; Volker, 2005). In addition, technology has embraced globalization as companies use marketing activities to create and sustain competitive advantages (Kotler and Keller, 2006: p. 329). In particular, e-commerce has made it easier and cheaper, and has simplified means, allowing consumers to interact with business firms electronically (Clemons et al., 2016). According to "Deutsche Welle, 2019" Alibaba, the Chinese e-commerce giant, is pushing into the African market. After opening up a digital trade center in Rwanda, East Africa in 2018, subsequently, opened a regional center for its World Trade Platform in Ethiopia, "a kind of digital international market- 
place for goods and financial products". The Chinese e-commerce giant hopes that small and medium-sized enterprises will benefit more from globalization.

However, steel producing companies are well-known for keeping their production costs low by balancing their manufacturing expenses to fend off competition from low-cost, low-price competitors. But, to meet those goals, the steel industry needs to undertake an initiative of change, such as application of advanced technologies to improve productivity, reduce risks, and increase the effectiveness of resources to remain competitive both in domestic and global markets (Tassey, 2014). Such transformations do not come without challenges that greatly impact the pricing of the finished end-products, which, in turn, drastically affect brand growth. Therefore, by implementing a precise marketing strategy steel industry players can overcome such challenges. For example, Arcelor Mittal Downstream Solutions (AMDS), European leader in the distribution of high-performance steel products to $\mathrm{B} 2 \mathrm{~B}$ and $\mathrm{B} 2 \mathrm{C}$ consumers, started e-commerce activities at the end of 2016 and launched its first web shop (online store, "e-steel”) in June, 2017 (First web shop for Arcelormittal/Sqli Digital Experience, 2016) to optimize its marketing activities and increase sales.

In Uganda, several similar studies were carried-out, including: developing the iron and steel industry-Harnessing the fruits, National Planning Authority. (2018); Options for improvement of the Ugandan iron and steel industry Senfuka et al., 2011; The evolution of industry in Uganda Obwona et al., 2014; Industrialization as a vehicle for Uganda to achieve a $1^{\text {st }}$ world economy by 2040 Muwanguzi et al., 2018; The prospects of Uganda's iron ore deposits in developing the iron and steel industry Muwanguzi et al., 2020a; Modelling the growth trend of the iron and steel industry: Case for Uganda Muwanguzi et al., 2020b; Second National Development Plan (NDPII), Kampala. National Planning Authority (2015/16-2019/20); and Marketing strategies and sales performance of manufacturing firms: a case study on Tembo steel limited in Uganda (Ngendahayo, 2019). Altogether, covering eleven dimensions: 1) Uganda iron and steel companies lack funds and organizational core technical competencies such as ceaseless innovation, marketing capabilities and financial risk management 2) lack of investment in technology and continuous use of old equipment causing frequent machines breakdowns resulting into low capacity utilization averaging below $55 \%, 3$ ) production of low quality, quantity steel and lack of raw materials coupled with shortcoming in product standardization resulting from the inconsistent chemical composition and poor mechanical properties cannot be ignored. 4) lack of steel scrap is causing stiff competition among steel mills. In such situations, supply of poor quality scrap is unavoidable, hence production of low quality steel that is threatening the steel industry's existence. 5) workers lack required technical skills because of no proper linkages between steel companies and research institutions to compliment on work skills and quality of products. 6) irregular power supply meant continuous casting in the steel making process is 
affected., 7) poor organizational structure 8) the culture of the organization or organizational DNA are lacking personality such as capabilities, innovation or speed, 9) challenges of infrastructure development 10) Uganda's limited manufactured products for global markets (Figure 1), and 11) although not documented in prior literature, the sector is also faced with rampant unfair trade practices manifested in tax evasion, falsification, substandard products and non-tariff barriers to trade. The results from Tembo steel case's study represent in wider context, all Ugandan steel customers' demands and marketing processes since Tembo steel limited is one of the Uganda's main steel producers.

- Price determination: Prices of set steel products in marketability are first of all determined by the cost of; production, delivery, and promotion. The products are charged fair prices that influence the consumer's perception of a product's value. They establish a significant relationship between price and sales performance. The price charged aids the company to generate high or low profit revenue and the most important customer satisfaction and loyalty factor depends on the interplay of the marketing mix by the marketing department.

- Product value: Uganda steel customers meet the price of the chosen product value for a specific purpose to receive a product or service for a certain value. This is the direct cost of the amount of money the buyer has to pay for the product bought. Thus, price is one of the factors affecting the consumer, because it aids them to evaluate the value of the product. Therefore, there is always an inverse relationship: the higher the price increment, the subsequent sales decline.

- Customized products strategy: Steel Products are made available to customers through making special orders (product customization) and the company directly distributes or delivers them. However, they also allow them to come to company outlets, warehouses, and also distribution agents. The distribution of products helps take steel products to places where consumers can have direct access to them.

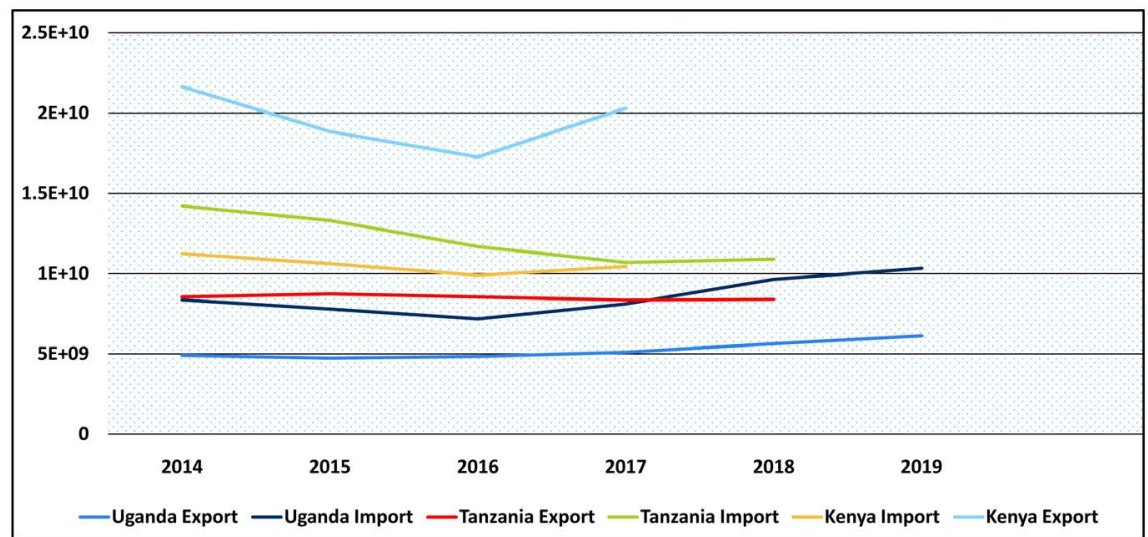

Figure 1. Exports, imports of goods and services (BoP, current US\$), East African countries. Source: World data bank, world development indicators. 
- Distribution function: The company focus on the distribution function is two ways: as a marketing channel, with the objective of providing service and making it more accessible to consumers; and physical distribution, that is attributed to technical feasibility, transportation, local conditions, and other conditions, depending on the nature of the service.

- Promotion strategy: company uses a promotion strategy to help disseminate product information, increase product purchase as well as the purchase decision process. Promotion attributed to an increment in the consumption of metallic products at least $1.2 \%$ in 2018 as compared to 2017 .

- Customer survey: The company conducted a customer survey in 2017 "the people's choice survey" under Uganda Manufacturing Association (UMA) gala night awards to determine consumption of metallic products, brand performance and competitors' strength in the market. The results were used to drew up new promotion strategy and win non-decided customers/individuals to increase market share.

Although, previous literature (Table 1) deals with collective terms for technologies and concepts of the organization of the value chain Arca et al. (2011), shift from vertical to horizontal integration and innovation process Rennung et al. (2016), a holistic system of information technologies Longo et al. (2017), organization overcoming challenges is a key to adapting to its logistical means and determining its scope Neeraja et al. (2014), and manufacturing systems which

Table 1. Summery of previous literature of industry 4.0 concept and scope.

\begin{tabular}{|c|c|}
\hline Author & Industry 4.0 concept \\
\hline $\begin{array}{l}\text { Moreno et al. (2017); } \\
\text { Anderl (2014) }\end{array}$ & $\begin{array}{l}\text { Manufacturing systems, vertical and network integration; } \\
\text { It is aiming at making a factory work intelligently with its } \\
\text { products and production processes, such as managing the } \\
\text { inventory, failures in machines, maintenance, and among } \\
\text { other aspects, are cyber-physical production systems (CPPS) }\end{array}$ \\
\hline $\begin{array}{l}\text { Rennung et al. (2016); } \\
\text { Sokolov and Ivanov (2015) }\end{array}$ & $\begin{array}{l}\text { Horizontal integration; companies focuses their activities } \\
\text { around its core competencies and establishes partnerships } \\
\text { to build out an end-to-end value chain. }\end{array}$ \\
\hline $\begin{array}{l}\text { Dombrowski and Wagner } \\
(2014) ; \\
\text { Longo et al. (2017); } \\
\text { Hermann et al. (2016) }\end{array}$ & $\begin{array}{l}\text { A holistic system of information technologies; allows flow of } \\
\text { data, goods and services through the entire value chain in a } \\
\text { controlled way. Operating with a high degree of autonomy and } \\
\text { capacity to transmit useful information for decision making }\end{array}$ \\
\hline $\begin{array}{l}\text { Toro et al. (2015); } \\
\text { Moreno et al. (2017) }\end{array}$ & $\begin{array}{l}\text { Integration of complex machinery and devices with software } \\
\text { networks and sensor; that help to control, predict, and } \\
\text { improve business planning and results in a society }\end{array}$ \\
\hline $\begin{array}{l}\text { Shafiq et al. (2015); } \\
\text { Arca et al. (2011); }\end{array}$ & $\begin{array}{l}\text { Collective terms for technologies and concepts of the } \\
\text { organization of the value chain }\end{array}$ \\
\hline $\begin{array}{l}\text { Trends (2015); } \\
\text { Prause and Weigand (2016) }\end{array}$ & $\begin{array}{l}\text { New level of organization and management of the value chain } \\
\text { throughout the product life cycle }\end{array}$ \\
\hline $\begin{array}{l}\text { Neeraja et al. (2014) and } \\
\text { Ltifi and Gharbi (2015) }\end{array}$ & $\begin{array}{l}\text { Organization overcoming challenges; It is a key to adapt to its } \\
\text { logistical means and determines its scope }\end{array}$ \\
\hline
\end{tabular}


enable a factory to work intelligently with its products and production processes Moreno et al. (2017). But, in Africa, specifically Uganda, where research was conducted, there is a gap in terms of industry 4.0 impact on marketing activities and strategies. Therefore, this study analysis is based on relevant factors of marketing activities when adopting industry 4.0 in relation to the cost of doing business considering challenges of infrastructure development and internet access. Thus, the study findings might be of great importance to practitioners, organizations, policymakers and other government agencies.

The objective of this paper is to seek and understand the impacts of the adoption of Industry 4.0 technologies on marketing activities of steel companies in developing countries and examine its effects in relation to the cost of doing business, in this case, Uganda. Although several media and literature pointed out Industry 4.0 as a technological transition happening at the factory level, changing the way products are manufactured. In such circumstances, marketing appears to play a marginal role in relation to production functions. From this point of view, engineers are overtaking managers. But, on the contrary, we insist that marketing is at the heart of the decision making of adopting companies. Our concept is that Industry 4.0 is a market-driven technology that enables companies to optimize the quality of customer relations, reduce risks and production costs, improve marketing capabilities and flexibility.

The main aim of this study is to investigate the impacts of Industry 4.0 on marketing activities and strategies of iron and steel companies in developing countries by identifying which consideration factors are relevant when adopting industry 4.0 in relation to the cost of doing business including; 1 ) the effects of rapidly evolving technological capabilities in marketing activities and strategies of steel companies implementing industry 4.0,2) effects of evolving organizations, and 3) ecosystem-wide connections impacts. Therefore, this study analyzed industry 4.0 in a broader context, taking into account existing literature, the new pressures and demands of evolving organizations, evolution of marketing activities, including; Marketing 1.0, Marketing 2.0, Marketing 3.0, Marketing 4.0, and features of each marketing stages and the differences among them. Finally, the impact of technology on marketing mix elements.

\section{Literature Review}

\subsection{Industry 4.0: A Brief Definition}

Industry is presently undergoing transitions that are entirely concerned with a complete manufacturing process digitalization. Technologies for smart manufacturing such emerging developments of Augmented Reality (laser cutting, Autonomous Robots, Additive Manufacturing) Simonis et al. (2016), Big Data Analytics, Cloud Computing and Mobile Technologies, Smart Sensor, Internet of Things (IoT) Toro et al. (2015), leading the emergence of the modern industrial digital revolution, termed as Industry 4.0 Almada-Lobo (2016). The $1^{\text {st }}$ Industrial Revolution, which took place in the late $18^{\text {th }}$ century, was characterized by mechanical production driven by steam and water power. The $2^{\text {nd }}$ Industrial 
Revolution that emerged in the $20^{\text {th }}$ century and led to the growth of mass production was characterized by electricity development, and in the 1970s, the development of computer and information technology that led to automation of production processes, ushered in the $3^{\text {rd }}$ Industrial Revolution.

Several authors; Arca et al. (2011), Hermann, Pentek, and Otto (2016) and Dombrowski and Wagner (2014) defined industry 4.0 in collective terms of technological scope and organizational value chains. Therefore, revealing both aspects of business and digital transformations needed to be implemented by the steel industry.

However, some authors have considered the importance of the holistic approach to Industry 4.0, which allows the flow of data, goods and services through the entire value chain in a controlled manner (Hermann et al., 2016), and Strandhagen et al. (2017), defines it as an "umbrella term" that is, referring to a number of concepts and effects on many disciplines in the industry. Below Table 1, are summery of some previous literature of industry 4.0 concept and scope.

\subsection{The Impacts of Industry 4.0}

The fourth industrial revolution or IoT is impacting on many areas in steel manufacturing and administration, most notably; industry value chain and new pressures and demands of steel companies implementing industry 4.0, connecting ecosystems to drive better decisions, empowering both workers and customers, causing marketing revolution, impacting on marketing activities and strategies, and marketing mix.

\subsubsection{New Pressures and Demands of Steel Companies Implementing Industry 4.0}

Industry 4.0 transformation concerns smart supply chain, smart manufacturing process, and smart products and individuals across the entire value chain. That is, digitalization of manufacturing processes, smart manufacturing technologies (automation so as to contribute to the operational efficiency and effectiveness of the company) and reorganization (Almada-Lobo, 2016; Oluyisola et al., 2020; Longo et al., 2017). However, most iron and steel companies in developing countries continue to struggle with the imperative of organizational and ecosystem-wide change which keeps on exerting pressures and demands on their operations amid infrastructure and internet access challenges, including; 1 ) increased complexity of the supply chain and global fragmentation of production and demand, 2) rapidly evolving technological capabilities, 3) organizational realignments as result of digital and physical technologies integration, 4) growing competitive pressures from unanticipated sources, 5) ongoing talent/skills gap, 6) illicit trade practices and 7) rising cost of doing business.

Therefore, Industry 4.0 provides options on how some of those challenges potentially can be addressed. That is, the integration of physical and digital technology in Industry 4.0, because it has the potential to adapt and learn from 
real-time data that can make steel companies more flexible, proactive and predictive, and help them to avoid operational downtime and other challenges in productivity (Parrott \& Warshaw, 2017).

Furthermore, the breakdown of how Industry 4.0 addresses the challenges of organizational and ecosystem-wide changes are attributed to twofold: improvement in operations and growth in revenue. Steel industry managers may pursue different opportunities in both areas, depending on where the focus of a company lies. Operating and developing a business map of various activities across the three main product areas, the supply network, process and customers (Hood \& Brady, 2016). The decision to either prioritize operation or growth will determine which areas may call for the greatest attention in terms of Industry 4.0 adoption and the choice of technologies that may warrant deeper investment.

\subsubsection{Connecting Ecosystems to Drive Better Decisions}

Industry 4.0 not only poses change at the broadest level in how businesses function, and products are manufactured, but also has technological capability to generate engagements between any point of a network of ecosystems and communicate with vendors, customers, investors, regulatory requirements, and other third-party experts and influencers (Sniderman et al., 2016).

This transition from linear, sequential business practices to an integrated, open structure will transform steel industry processes and lay down the groundwork for the future of how businesses work, interact, and compete.

\subsubsection{Empowering Both Workers and Customers}

Industry 4.0 is most likely to affect the working environment of a steel company, the way employees are expected to do their jobs, and how they are expected to do it. Thus, emphasizing on customization of products and services that better suit their needs could be essential.

- Shifting demands for the workforce: In this Industry 4.0 era, the rise of smart automation and ubiquitous connected systems seems to herald a change in what steel companies might require of their employees: skills requirements, tasks needed to be performed, even what roles they might need. In a similar organization, data troves may be generated, as the combination of digital and physical environments that will compel employees to perform complex, variable and sometimes unpredictable tasks that involve the ability to access and understand data. However, smart digital and physical technology can be employed as instruments to develop the work of steel employees to simplify tasks. Their efforts can also go beyond that to a wider relationship in which autonomous technologies work together with individuals, each exploiting their intrinsic strengths to achieve a better result than either alone could achieve. This can enable rise to entirely new positions, just as they allow new products and services (Hood \& Brady, 2016).

- A more suitable, engaging experience for customers: Industry 4.0 offers new dynamics in the way modern steel sales are conducted, ranging from initial research, sales to account management, and post sales support at any 
stage of the consumer. Via its goods, services, or other touch points, consumers communicate with the steel company in some way, generating data that can be analyzed and used to drive an intervention of new customized desires or behaviors (Hood \& Brady, 2016). In addition, it offers better understanding and even predicts steel customer preferences based on aggregated historical engagement and data from other customers or feed back into the research and development process to form better-designed offerings (Witkowski, 2017).

\subsubsection{Causing Marketing Revolution}

Marketing revolution started from marketing 1.0 to current marketing 4.0. According to Chartered Institute of Marketing, "Marketing is the management process responsible for identifying, anticipating and satisfying customer requirements profitably". But, the first recognized definition of the marketing concept was presented in the 1960's by the American Marketing Association (AMA) See (2007), "the development of economic activities (business activities) that direct the flow of goods and services from producers to consumers". Marketing has evolved from a product centric marketing concept to a new age marketing concept of managerial, social and virtual reality approach which considers the need to create a certain important value for the consumers, community and the company. So, to get a clear understanding of shift from selling goods and products to managerial, social and virtual reality concepts, we need to examine evolution processes from marketing 1.0 to marketing 4.0.

- Marketing 1.0: The Marketing 1.0 concepts as explained by marketing theoretician, professor Philip Kotler, known as "the father" of modern marketing, has been practiced from the industrial era until the first half of the $20^{\text {th }}$ Century, is based on a traditional interactive approach that focused mostly on products and services offered by companies. The concept was simply about creating very attractive selling points. Kotler et al. (2010).

- Marketing 2.0: The second evolution of the marketing concept, was Marketing 2.0. The key feature of this concept is that it uses information technology and its tools to manipulate and distribute information. It promotes the features and functionality of products. The concept focused more on customers to identify and satisfy their needs, then create loyalty. Thus, by creating specific aims of marketing efforts and targeted market, it was able to replace traditional mass marketing with audience segmentation Kotler et al. (2010).

- Marketing 3.0: From the marketing 3.0 perspective, marketing is brought into the arena of human aspirations, values, and spirit. It is based on a new wave of technological developments and its essential tools: the internet, social media, computer and mobile phones. That is, Social Media Marketing (SMM). Instead of companies relying on statistics and past trends, direct communication with customers base provides real-time data and indicators. Hence, decision-making processes can be taken into account as a result of knowledge 
generated through interaction with clients, analysis, then objectives are met. Therefore, Marketing 3.0 blends emotional marketing with human spirit marketing (Kotler et al., 2010).

- Marketing 4.0: According to (Kotler et al., 2017), Marketing 4.0 relates to "a marketing approach that combines the online and offline interaction between companies and consumers". On the other hand, it blends machine or artificial intelligence with other Information Telecommunication and Computing (ITC) technologies to increase productivity, while at the same time, it leverages human to human connectivity to improve the consumer interaction process. It is focusing mostly on customer interactions and increasing demands for companies to improve their channels and downstream communication approach.

Table 2 shows how evolution in technology sparked the shifts from product-centric to consumer behaviour, followed by market values and new-age virtual marketing due to the emergence of new marketing applications.

Table 2. The main differences among marketing concepts.

\begin{tabular}{|c|c|c|c|}
\hline Specification & Concept & Key feature & Key transition \\
\hline $\begin{array}{c}\text { Marketing } \mathbf{1 . 0} \\
\text { Kotler et al. (2010) }\end{array}$ & $\begin{array}{c}\text { Product-centric } \\
\text { (Product development) }\end{array}$ & $\begin{array}{l}\text { - Sell products \& Services } \\
\text { - Mass buyers with physical needs } \\
\text { - Product development } \\
\text { - Product specification } \\
\text { - Functional value } \\
\text { - One-to-many transaction }\end{array}$ & $\begin{array}{l}\text { - Industrial } \\
\text { revolution }\end{array}$ \\
\hline $\begin{array}{c}\text { Marketing } \mathbf{2 . 0} \\
\text { Kotler et al. (2010) }\end{array}$ & $\begin{array}{l}\text { Customer-Oriented } \\
\text { (Differentiation) }\end{array}$ & $\begin{array}{l}\text { - Satisfy and retain customers } \\
\text { - Smarter consumers with mind } \\
\text { and heart } \\
\text { - Differentiation } \\
\text { - Corporate and product } \\
\text { positioning } \\
\text { - Functional and emotional } \\
\text { - One-to-one relation }\end{array}$ & $\begin{array}{l}\text { - Information } \\
\text { technology }\end{array}$ \\
\hline $\begin{array}{c}\text { Marketing } \mathbf{3 . 0} \\
\text { (Kotler et al., 2010) }\end{array}$ & $\begin{array}{l}\text { Value-Driven } \\
\text { (Value) }\end{array}$ & $\begin{array}{l}\text { - Make the world a better place } \\
\text { - Smarter consumers with mind } \\
\text { and heart } \\
\text { - Values } \\
\text { - Corporate vision and values } \\
\text { - Functional, emotional and } \\
\text { spiritual } \\
\text { - Many-to-many cooperation }\end{array}$ & $\begin{array}{l}\text { - New wave } \\
\text { technology }\end{array}$ \\
\hline $\begin{array}{c}\text { Marketing } 4.0 \\
\text { (Kotler et al., 2017) }\end{array}$ & $\begin{array}{l}\text { Localized Virtual } \\
\text { Marketing } \\
\text { (Mass } \\
\text { customization, JiT) }\end{array}$ & $\begin{array}{l}\text { - Today create the future } \\
\text { - Collective of fully conscious } \\
\text { buyers } \\
\text { - Mass customization, \& } \\
\text { Just-in-Time (JiT) Production } \\
\text { - Values, vision and anticipation } \\
\text { - Functional, emotional, spiritual } \\
\text { and self-creative } \\
\text { - Many-to-many co-creation } \\
\text { and cooperation }\end{array}$ & $\begin{array}{l}\text { Cybernetic } \\
\text { revolution } \\
\text { and Web } 4.0\end{array}$ \\
\hline
\end{tabular}




\subsubsection{Impacting on Marketing Activities}

The effects of industry 4.0 of network within the IoT, services, data and people has transformed steel manufacturing processes as well as marketing activities and its shaping the future. Some notable changes are as follow:

- Caused change towards interconnected consumers: In the context of information technology developments, the greatest challenge is to adjust to fast information technology driven change. To adapt to these new environments, steel companies have to undertake changes, including; implementing new technologies, reorganization, marketing strategies and people in order to increase productivity and efficiency, human connectivity, and customer interaction processes. These changes brought by the internet age or virtual reality are not only affecting businesses but also affecting consumers, business professionals, communities, and individual lives as well Kotler et al. (2017).

- The change from vertical to horizontal: Globalization has facilitated smaller companies to compete with large corporations for the same customers. The ability for a smaller steel company to access products and services worldwide made it possible. The shift from vertical to horizontal innovation process, that is, the historic ways, from the company to the market, does not work any longer. Larger corporations have been forced to change strategies and draw inspiration from external sources rather than from within. That is, from consumers and the market. It is a change from vertical individualized and customer specific production operations to horizontal new age globalized value creation networks, including integrated business partners and customers, and new generation businesses and cooperation models from across the world. Useful examples, in 2006, Mittal Steel acquired Arcelor (steel) and Facebook's 2012 acquisition of Instagram (social media), in order to form horizontal strategic alliances or joint ventures to exploit a new marketing opportunity.

- Marketing shift from exclusive to inclusive: The change from exclusive to inclusive ranges from technology, demographic, emergent to transparency and social elements. The current demographic economic shift is attributed to an emerging market population with younger consumers who are more productive, and have a higher economic level; it can also be seen from the technology aspect of steel companies implementing industry 4.0, investment in research and innovation has increased, new technologies and production methods. In addition, products design such as computers and mobile phones are becoming smaller, lighter, and smarter; shift from Western powers to Asian emerging powers like China and South Korea, that is, macro-economical shifts; and business itself is shifting towards inclusivity, that is, technology enables, such automation in steel production processes, and miniaturization is cutting costs of production down enabling steel companies to serve the new emerging markets in Africa; and the emergence of Internet technology has promoted globalization and transparency, entrepreneurs from developing countries can now have the opportunities to draw inspiration from their 
counterparts in developed countries, e.g., Grab in Malaysia was inspired by Uber and Jumia in East Africa was inspired by Alibaba in China Kotler et al. (2017).

- From individual to social: The emergence of internet technology has drastically changed the dynamic of communication and the way we do certain things. An individual decision making process that used to be influenced by factors such as motivation, preference, opinion or experience of others. Nowadays, it is more diverse and exogenous due to social media platforms and online communication. It is estimated that more than 2.1 billion population worldwide have active Facebook accounts (Facebook.com Internal Statistics, 2019), So, steel consumers' decisions regarding certain products and services can be influenced by opinions posted on such social media platforms. Such a shift in mode of communication between customers-companies and customers-customers is already yielding good results and will even get better with the development of smartphones and internet usage. The transparency and environment of online interaction brought by internet technology has shifted our lives from individual to social ones (Kotler et al., 2017).

\subsubsection{Impacting on Marketing Strategies}

In the last decades, the world has witnessed notable shifts in marketing strategy on how value is delivered to targeted groups or fields (Kotler et al., 2010).

- Marketing the mission to consumers: This is related to human spirit marketing where steel companies successfully implant a brand's mission into consumers' minds, hearts, and spirits. It is all about undertaking initiatives to make a brand transform the way customers do things in their lives. This way, consumers are unconsciously willing to accept brand as part of their daily lives. Identify small ideas to market company product's mission to consumers, sell company brand by telling stories that move people. Remember, mission comes first, then financial benefits as the result.

- Marketing the value to the employees: The traditional mindset embedded in most steel companies is that if we talk nicely about who we are, what we sell, and why we are the better, we will reap good sales. But, the impact of digitization on the economy, especially from corporate perspectives, does not apply anymore. For those reasons, some steel companies had to endure hardship with their brand not because of customers but because of failure to understand the basics. So, where do we start from? Steel companies must start from the basic by recognizing its employees as internal clients. Employees know better the company, brands, products and services and need to be empowered with the most significant values. Subsequently, employees will use their knowledge of the company, values, and principles to build a long lasting relationship with customers.

- Marketing the value to the channel partners: In the era of Marketing 3.0 and 4.0 integrating business operations is necessary, and it requires new techniques that generate value and participles to stabilize the market. Based 
on this concept, steel company activities along the entire value chain need improvements and, besides, when choosing channels partners such as companies, employees, public authorities, suppliers, and consumers, the steel company needs to take into consideration the core principles and values of the company for compatibility reasons Kotler et al. (2010).

- Marketing the vision to the shareholders: We all know that the reasons we do business are for profit making, and shareholders are the business owners. So, it is necessary to keep steel company shareholders updated of the new changes taking place in our lives, market and consumer behaviors. On the other hand, shareholders should also be made aware of the new marketing concepts of Marketing 3.0 and 4.0, including practicing sustainability strategies that come along with it for sake of profitability and rentability reasons.

\subsubsection{Impacting on Marketing Mix}

Technological advancements aroused the evolution of steel marketing activities. It has simplified and accelerated the processes with the application of new tools and techniques (Jayaram et al., 2015). In this industry 4.0 era, the capability to adapt to technological developments has become one of the most valuable assets of a steel company. Therefore, it is necessary for them to re-think their marketing mix elements such as product, price, place and promotion strategies based on the new-age technologies.

- Product: Developing and selling tangible or intangible products that your customers actually need is crucial to your business's prosperity (Buttle, 1989). For quite sometime now, it has been observed that technological development comes along with different physical changes in products and services. That is, the introduction of product standardization, bulky production, customization of products, shelf life extension, personalized products and smarter products. Bennett (2013) argues that products of being very central to any marketing activity. So, any change in product type, size, color, or specifications will ultimately affect other marketing mix especially price and promotion expense.

Steel companies and other manufacturing industries have developed their operations with technology change, high production capacity with increased speed as application of assembly line technologies in manufacturing allows business to conform to mass production (Adetayo et al., 1999: p. 691).

As the Marketing 1.0 strategy was product based, the focus was on mass production regardless of customers' desires. Every business aimed at maximizing profits by diminishing the cost of production with standardization of products. As manufacturing technologies improved and competition increased, businesses responded by producing high quality products as a means to differentiate themselves, Marketing 2.0.

Internet technology has emerged, allowing consumers to interact with businesses globally and have alternative choices of products as well as enabling consumers to become more conscious of their particular needs and desires (Cle- 
mons et al., 2016; Rust \& Espinoza, 2006: p. 1073). As a result, industries shifted from mass production to individualized production, which led to the Marketing 3.0 era. Products have become smarter in nature, product designs such as laptops, mobile phones become smaller, lighter and smarter, whereas, environmental conservation issues have become a significant part of product design too.

In Marketing 4.0, CPPS allows communication flow among mechanical, electronic components and human beings via a system network, increasing human machine connection. Engagement of customers by use of Quick Reaction (QR) codes on product packages and advertising messages so that consumers can get access to all information such as, price, availability, and quantification by scanning these codes. Besides, a breakthrough in product strategy occurs thanks to IoT technology (Zhang et al., 2012: p. 1069). IoT is a new age technology that enables physical machines to be controlled by remote sensors (Kopetz, 2011: p. 307). But, industry 4.0 is not only a technological revolution in physical products but also offers solutions for consumers to easily access information about services they desire through; web sites, search engines, social media, videos, satellite images, forums, animations, photos and blogs (Sari \& Kozak, 2005: p. 261).

The introduction of interoperability technology has helped iron and steel companies in product standardization process and solves the issues arising from service companies about product feature variation. Thereof, Marketing 4.0 era is seen to have impacted on both physical goods and services (Buhalis and Law, 2008: p. 614).

- Price: The interactivity, simplicity and universality of the global world brought by advancement in technology is playing a big role in product price strategies.

Advancement in information technology can not only aid steel companies to compare prices (Shift from closed to open pricing methods) with their competitors, but also aids customers to compare prices of products available in the markets (Booms \& Bitner 1981; Sharma \& Sheth, 2004). The price of products in the market influences consumers' decisions since they are similar in terms of quality, quantification, and price (Kotler, 2012).

The ability of iron and steel companies to access resources from any part of the world is working perfectly well to their advantages irrespective of company size, as it helps to recruit raw materials, get new market, and cheap labor, reducing the cost of doing business. Furthermore, little or no taxes at all are levied on e-commerce firms (Sharma and Sheth, 2004: p. 700).

- Place: When the 4Ps initially developed, place was a term used to a greater extent to refer to shop displays, physical advertising and supplier chains. However, with technology advancement, the distribution function of 'place' in the B2B or industrial marketing is shifting. Steel manufactures are beginning to sell their products via their websites. Hence, simplifying and enabling effective management of distribution channels (Waters, 2003: p. 29).

The emergence of internet technology and omnichannel is impacting on place 
by partly/wholly substituting or reducing the cost of running intermediaries like training of staff, providing people to explain product features and marketing of products as well as selling of goods and services. Steel consumer buying behavior such as presence or absence of other customers at stores, which used to be one of the contributing factors, is changing since most of these services are provided online Rafiq and Ahmed (1995).

However, contentious coordination among steel channel members aided by increased communication facilities accelerates sharing of business information. Hence, it ensures efficient inventory management (Tekin \& Zerenler, 2005: p. 118). Also, consumers and channel members can communicate in real time at less cost. This could be one of the important competitive advantages information technology has brought to steel firms (Closs and $\mathrm{Xu}, 2000$ : p. 882).

Steel firms are now able to apply various lebelling technologies such as frame code, barcode, and FRID code for consumers to scan and get required information about product price, qualification, and availability. Lebelling technologies also help firms to take precautions of faults arising from employees (Sun, 2012: p. 108). The transactions are recorded at instant sales by scanning of these codes, as well, sales frequency of specific products can be apparently monitored (Moncrief and Cravens, 1999: p. 331). Data derived from these labelling technologies can be used by business firms in evaluating and managing future inventory levels.

General positioning services (GPS), is another notable significant technology development being used by iron and steel companies in management of distribution channels. This system uses satellites to tracks location of all goods/vehicles in transit.

- Promotion: is a great idea to sell and display stuff in an encouraging and flattering way. It covers perspectives such as personal selling, public relationship (PR), corporate identity, advertising, and mostly every part of marketing communications Ferrel et al. (2002).

During the Marketing 1.0 era, marketing communication was a one-way aimed at reaching a mass population where consumers were termed as passive listeners of mass messages of business (Chen and Hsieh, 2012: p. 543). However, development in information technology rolled in new-era for promotion, introducing interactive communication. That is, Web 2.0. Customers were able to receive personalized communication massages allowing businesses to initiate one to one interactive relationship with customers. The interactive relationship of one to one intensity increases with Web 3.0 and Web 4.0. Thus, fundamental change in marketing communication started from one-way communication in marketing 1.0; interactive communication in Web 2.0; and business advertising messages transforming from mass content to personalized content in Web 3.0 and Web 4.0 (Li and Du, 2012: p. 4).

Another major fundamental change that has occurred in the marketing communication strategy that clearly differentiates the traditional media from the new age technology of the internet and mobile is that traditional advertisements 
apply push type strategies, while the modern internet and mobile technology apply pull type advertising strategy ( $\mathrm{Li}$ and $\mathrm{Du}, 2012$ : p. 2).

In push type advertising strategy, firms try to transmit their advertising messages by grabbing customers' attention and putting products into their minds, while on the other hand, in pull-type strategies, businesses target the right customers at the right time by advertising messages (Chen and Hsieh, 2012: p. 544). While the customers are exposed to marketing massages in the push-type advertising strategy, customers receive marketing massages willingly in the pull type strategy (Peattie \& Peters, 1997: p. 148).

It is well understood that consumers are unwilling to read irrelevant advertising messages in newspapers and magazines and they change channels the moment advertising starts on TV and radio (Kotler, 2012: p. 110). But, due to the interactive nature of the internet, it has impacted on steel manufacturing companies, consumers' buying behaviour, pricing, relationship building, segmentation, promotion, distribution, and product management (Yannopoulos, 2011).

Against that background, firms, including steel companies, alter their advertising content into viral content so that it can arouse curiosity in the customers' mind and enjoy them (Chen and Hsieh, 2012: p. 545). In addition, social media is more effective in crisis management compared to negative words of mouth businesses experienced in the past.

\section{Research Methodology}

In this research, the authors used descriptive study with deductive approach, a survey strategy to collect primary data in questionnaire format. The questionnaires were sent to participants via Wechat, whatsapp, SMS for mobile users, Facebook, and through email. One of the researchers' main targets during a survey process is to achieve a higher response rate. Therefore, prior communication were given to participants, questions were designed carefully, proper attention was given to questionnaire layout, and the purpose of questionnaire was included in a letter head (Saunders et al., 2009).

\subsection{Sample}

The sample for this research has been drawn from Uganda's iron and steel industry to examine the impact of industry 4.0 on marketing activities. The research results are important for the whole developing countries context especially East African region, although data were collected only in Uganda. According to (Sada El-Balad English, 2020), Uganda economy is among the top 10 world's fastest growing economies and the growth is supported the national planning frameworks (National Planning Authority, 2010, 2015) that has earmarked on the development of the country's iron and steel industry, based on its existing iron ore deposits, among the key interventions to be used to achieve the desired vision by Uganda's Vision 2040 that aims at transforming its society from a peasant society to a modern prosperous one within 30 years through in- 
dustrialization (Muwanguzi et al., 2018; Muwanguzi et al., 2020a, 2020b). Besides, Uganda iron and steel industry is strongly connected to multi-nationals joint ventures. The shares owned by foreign capital in Uganda iron and steel companies almost half of the total capital. This interconnection of Uganda steel companies with foreign corporations and investments across boarders, e.g., Uganda Baati Ltd, which is one of the subsidiaries of the Safal group from South Africa. Safal group is one of the leading suppliers of roofing and other construction materials in the markets of Eastern and Southern Africa (Kenyanz.com, 2021), and Roofings Group (Roofings Rolling Mills Ltd \& Roofings Ltd.), often referred to as Roofings, is the largest manufacturer of steel construction materials in Uganda opened it branch in Rwanda Kwihangana (2014) with market coverage in Eastern and Central Africa leads to the conviction that the results can be generalized for the whole of developing countries in Africa.

The experts, mainly marketers from the major iron and steel companies and all its affiliates in Uganda agreed to participate in the research on the condition of assurance of anonymity in the sense that statements made would not be attributed to them by name. The computer assisted quantitative analysis technique was applied to convert collected primary data in to meaningful graphs, charts, and statistics using computer software's; SPSS, Excel, and Google drive form. The data collected and used in this study is defined with $5 \%$ margin of error (Saunders et al., 2009).

The sampling frame is Uganda's iron and steel producers and all its affiliates. The total population is estimated to be about 30,000. According to Saunders, Lewis and Thornhill (2009: p. 219) the sample size for 30,000 thousand employees are 150. However, there are refusals to respond the questionnaires. In this paper, the researcher estimated $72 \%$ refusal rate. The actual sample size are calculated as follows

$$
\begin{aligned}
\text { Actual Sample size } & =\text { Sample Size/percentage of response rate } \\
& =150 / 28 \% \\
& =535
\end{aligned}
$$

Among 535,400 are distributed in google forms.app, whatsapp, wechat, facebook and the rest in, email. Of the 400 survey forms, 350 marketer received the forms and 120 (32 percent) returned the filled-in forms. After data cleaning for normality and outliers, 91 of the 120 (76 percent) responses were used in the final analysis.

\subsection{Measure, Reliability and Validity}

As cited by (Allahverdi et al., 1999) about the reliability and validity of the research questions, this research questions were first done by the researchers then it was submitted to an expert in the marketing management. In addition to that the researchers distributed the questionnaires to some of steel workers through whatsapp, Wechat, Facebook users and marketing managers in Uganda iron and steel companies to collect Pre-test data on the questionnaires and the procedure 
of data collection. This ensured that the questionnaires are reliable, that the participants respond following the instructions and ensure that clarity and modification are done accordingly.

Validity of a survey questionnaire refers to the degree to which the survey questionnaire actually measures what it is designed or intended to measure. Authors used previously validated self-report measures. These measures have been used in marketing and organizational behavior literature (Rozell et al., 2006; Lee and Turban, 2010). The respondents were represented with the list of the challenges and then asked to indicate in a 5-Point Likert Scale questionnaire format Likert (1932). The authors evaluated the instruments using the scale for which 1 = strongly disagree, 2 = somewhat disagree, 3 = neutral, $4=$ somewhat agree, and $5=$ strongly agree. Several studies have reported high internal consistency and validity for this scale (Rozell et al., 2006; Cronbach's alpha $=-0.85$ ). Data was entered in the Statistical Package for Social Sciences (SPSS) and Cronbach's alpha coefficient test of reliability was calculated.

\subsection{Research Questions}

Based on research theoretical background and literature review, the author examined Uganda iron and steel manufacturers in a wider context ranging from technological, organizational and eternal effects resulting from industry 4.0 technological revolution in term of business cost Figure 2, considering significance of research results the research questionnaires were designed to cover those gaps and the following information was requested from respondents:

1) Gender of respondents;

2) Age of respondents;

3) Academic qualification;

4) Position of respondents in the company;

5) How does industry 4.0 technologies effect the elements of industrial marketing strategy/activities;

a) Website foundation (e.g., Search Engine Optimization-SEO)

b) Technology stack (e.g., Customers Relationship Management-CRM)

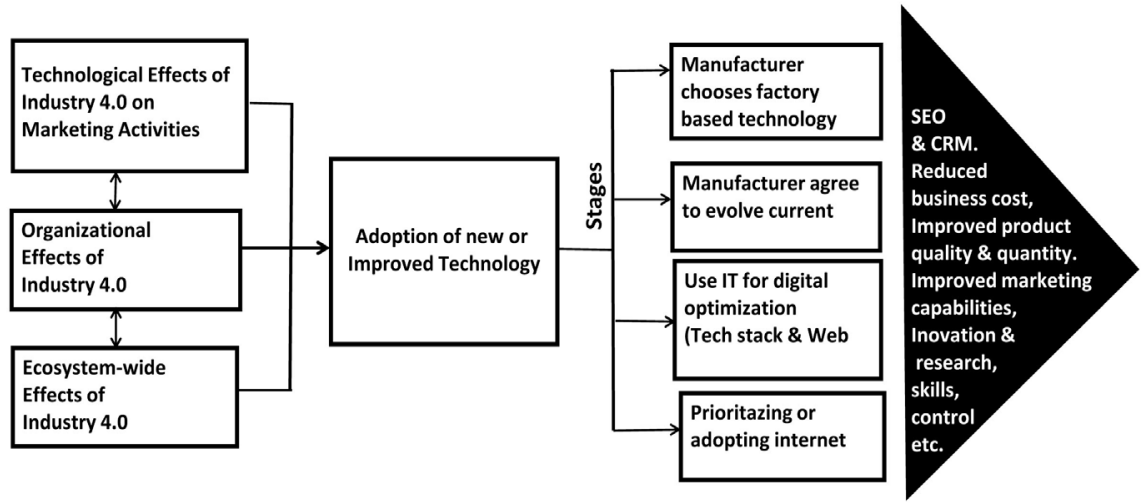

Figure 2. Research conceptual framework. 
c) Content strategy (e.g., Content Management System-CMS, Integrated Content Creation/Optimization and Content Syndication/Promotional Tools)

d) Positioning in the market

e) Data analysis (Analytic Tools)

f) Lead generation/Nurturing

g) Pipeline management

h) Channel strategy

6) How does industry 4.0 effects of evolving organizations and ecosystem-wide adaptation pressures and demands is impacting on;

a) Cost of doing business

b) Product quality, quantity, and raw material

c) Organizational realignments resulting from the integration between physical and digital technologies

d) Value addition and government incentives

e) Rapidly evolving technological capabilities

f) Ongoing challenges, including; skills gap, research and innovation

g) Increased supply chain complexity and global fragmentation of production and demand

7) Effects of illicit trade practices in the Uganda iron and steel industrial market;

8) And participants were provided with free space or opportunity to suggest possible solutions.

\subsection{Data Analysis}

\subsubsection{Demographic Characteristics of the Respondents}

To obtain data about demographic information of respondents which constituted age, education level and number of employees in the company. Questions 1 - 4 were administered and the following was revealed.

1) Gender of respondents: The researchers sought to investigate the distribution of respondents by gender. This was presented as in Figure 3 below.

2) Age of respondents: The researcher sought to investigate the age of the

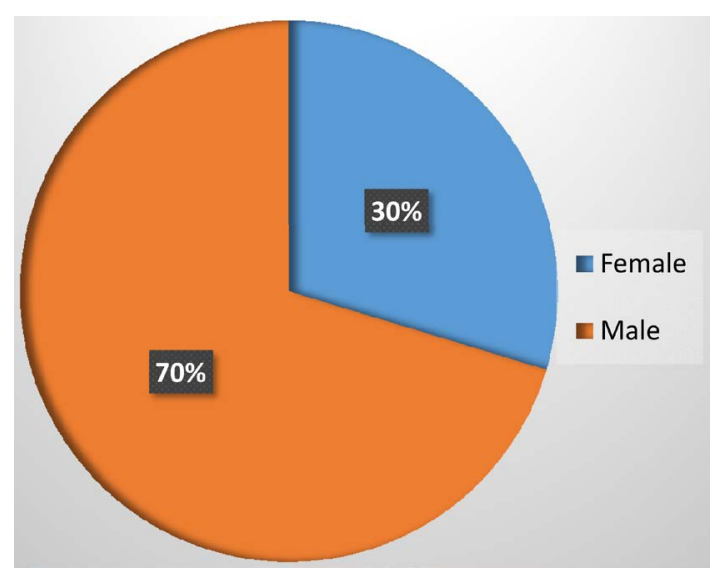

Figure 3. Pie chart showing gender distribution. Source: Primary data. 
respondents. Results on the age of respondents were established as presented below.

Findings in Figure 4 below revealed that $12(13.1 \%)$ of respondents were between the age of 18 - 25 years, 18 (19.7\%) were between 26 - 30 years, 26 (28.9\%) of the respondents were between 31 - 35 years, 20 (21.9\%) were between 36 - 40 years, 15 (16.4\%) of respondents were 41 years and above as shown in Figure 3 above. This shows that Uganda iron and steel companies and its affiliates employed adults who were experienced about marketing activities.

3) Level of Education: The research investigated the respondent's education level of the respondents. In response, the following were established.

The findings in Figure 5 below illustrate that 4 respondents had high school certificates this represents 4\%, 27 respondents have diplomas representing 30\% of the sample, 51 respondents had their first degree (56\%), 8 respondents had master degree representing $9 \%$ and lastly 1respondent had a $\mathrm{PhD}$ representing $1 \%$. This outcome implied that majority of the respondents had knowledge about the research topic and competitiveness of Uganda's iron and steel marketing job markets.

4) Respondents position in the company: The research investigated the respondent's roles in the company. In response, the following were established.

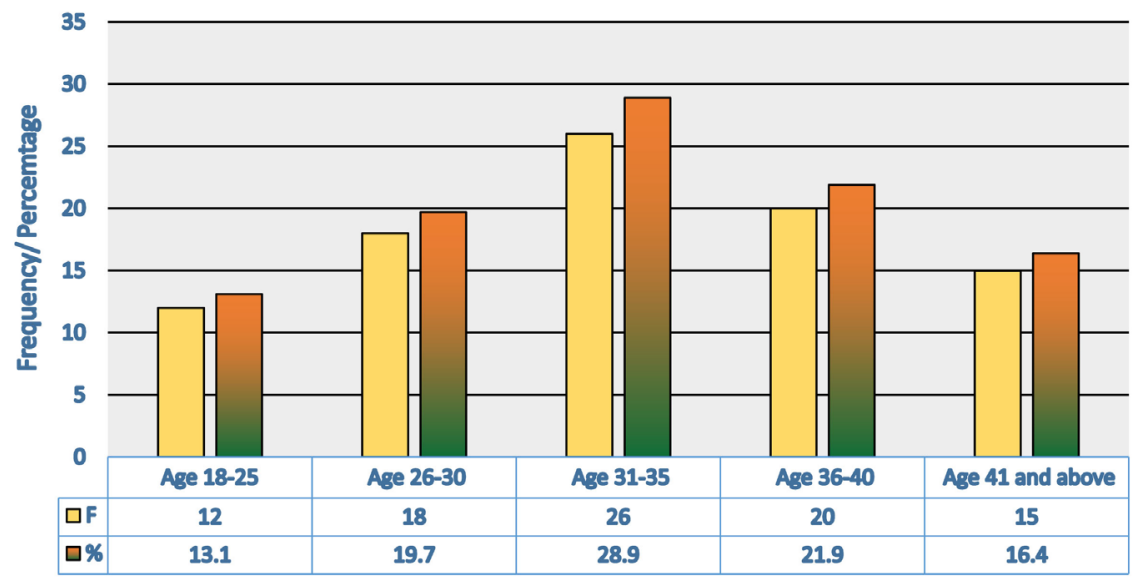

Figure 4. Age of respondents, Source: Primary data.

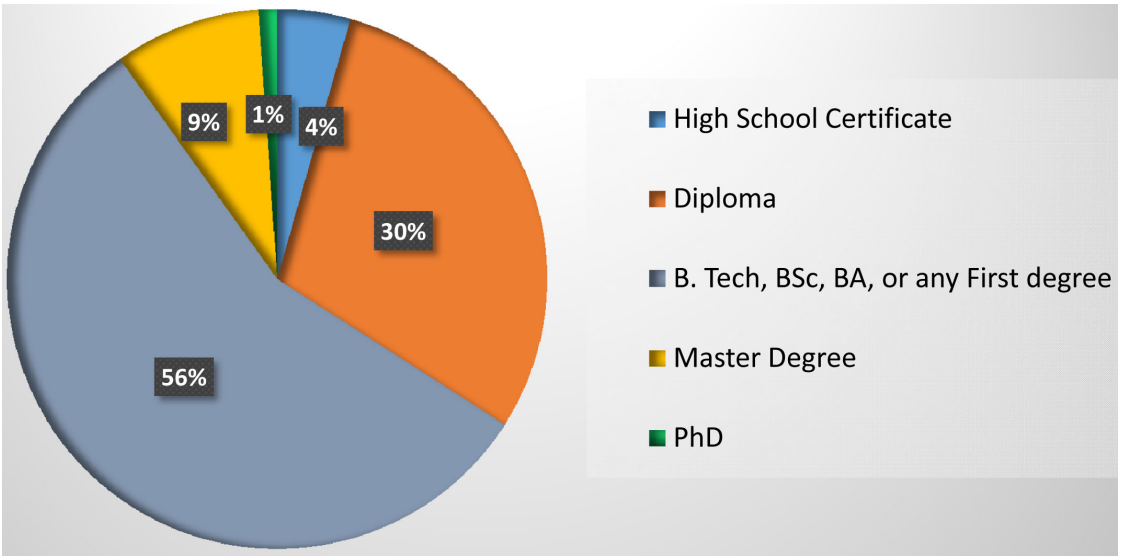

Figure 5. Level of education, Source: Primary data. 
The findings in Figure 6 below illustrate that majority of respondents constituted frequency of 60 workers, 12 business agents, 11 managers and 8 business owners. This demonstrates organizational set-up of iron and steel firms in Uganda.

\subsubsection{Descriptive Statistical Analysis of Variables}

In a bid to establish the reasons, why Nowadays, in Uganda there is a need for iron and steel manufacturers to invest in new or improved technology specifically how Industry 4.0 technologies affects the elements of industrial marketing strategy including; positioning, technology stack, website foundation, content strategy, lead generation, pipeline management, channel strategy, and data analysis (questionnaire 5), and those issues raised in questionnaires 6, and 7. Respondents were asked several questions to rate on the Likert scale. The highest score was strongly agreeing (5) and the least being strongly disagree (1) to the various test statements on the industry 4.0 technologies effects of evolving organization pressures and demands such as; organizational realignments, value addition, increased supply chain complexity, technical skills gap and research, evolving technology capabilities, product quality, quantity, lack of raw material, effects of illicit trade practices, and elements of industrial marketing strategy. Results were tabulated, interpreted and analyzed in Table 3 below.

Table 3. Descriptive statistics of variables.

\begin{tabular}{lcc}
\hline \multicolumn{1}{c}{ Items } & Mean & SD \\
\hline Cost of doing business & 4.23 & 1.096 \\
Product quality, quantity, and raw material & 4.31 & 1.029 \\
$\begin{array}{l}\text { Organizational realignments resulting from the integration between } \\
\text { physical and digital technologies }\end{array}$ & 4.47 & 0.993 \\
Value addition & 4.41 & 0.977 \\
Rapidly evolving technological capabilities & 4.43 & 0.956 \\
Ongoing challenges, including; skills gap, research and innovation & 4.12 & 1.073 \\
Increased supply chain complexity and global fragmentation of & & \\
production and demand & 4.36 & 1.017 \\
Effects of illicit trade practices in the Uganda iron and steel industrial & & \\
markets & 4.26 & 0.941 \\
Positioning & & \\
Website foundation & 4.20 & 0.934 \\
Technology stack & 3.23 & 1.257 \\
Content strategy & 3.02 & 1.141 \\
Lead generation/nurturing & 3.74 & 1.124 \\
Pipeline management & 3.60 & 1.228 \\
Channel strategy & 3.75 & 1.071 \\
Data analysis (Analytic Tools) & 4.20 & 1.128 \\
Grand total & 3.81 & 1.192 \\
\hline
\end{tabular}

Source: Primary data, $\mathrm{SD}=$ Standard Deviation. 


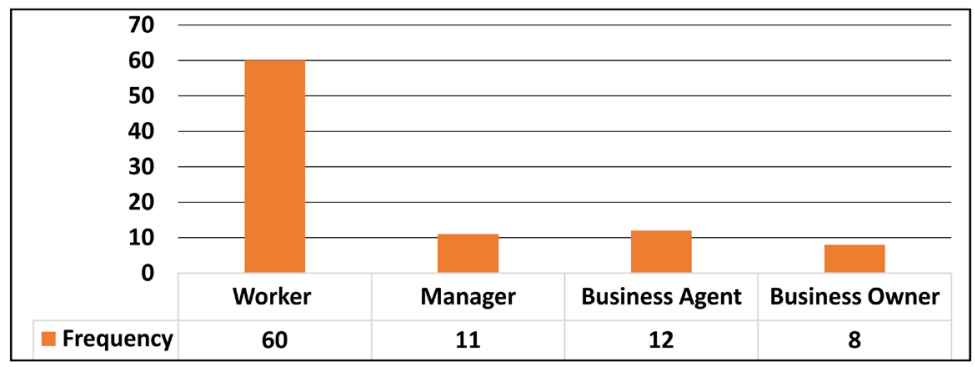

Figure 6. Respondents position in the company, Source: Primary data.

- Effects of evolving organizations and ecosystem-wide adaptation pressures and demands, and effects of illicit trade practices

The results in Table 3 above indicate that respondents agreed with the industry 4.0 challenges of skills gap, research and innovation (mean $=4.12$; $\mathrm{SD}=$ 1.073) having the highest effect and argued that despite, Uganda government efforts to open up technical institutes in every sub-regions which is yielding positive results, but still lack funding in addition to only handful of industrial research centers being functional. Furthermore, rising cost of doing business (mean $=4.23 ; \mathrm{SD}=1.096)$, and value addition (mean $=4.41 ; \mathrm{SD}=0.977)$, are among the pressing challenges facing Uganda iron and steel companies. However, product quality, quantity and lack of raw materials (mean $=4.31 ; \mathrm{SD}=1.029)$ is down to traditional manufacturing methods, limited foreign investment, limited local and foreign markets also have significant effects. Meanwhile, the increased supply chain complexity and global fragmentation of production and demand (mean $=4.36 ; \mathrm{SD}=1.017$ ) approval is due to respondents still have doubts or fear that poor infrastructure development, and existence of illicit trade practices (mean $=4.26 ; \mathrm{SD}=0.941$ ), such as market manipulation, tax evasion, and falsification would still affect the cost of doing business and supply chain as confirmed by United Nations Conference on Trade and Development report. "Africa loses nearly $\$ 89$ billion a year to illicit cash flows, such as tax evasion" (30 September 2020, UN Report/Aficanews, 2020). The low levels of appreciation of the effects of rapidly evolving technology capabilities (mean $=4.43 ; \mathrm{SD}=$ 0.956 ), and organizational realignments (mean $=4.47 ; \mathrm{SD}=0.993$ ), may also be due to fear on exposing illicit trade practices as earlier mentioned as regulatory bodies and company managers are becoming more vigilant and advanced in their approaches to market regulation.

\section{- The level of industry 4.0 technologies effects on elements of industrial marketing strategy/activities}

Further analysis of results in Table 3, respondents unanimously agreed that technology stack (mean $=3.02$; $\mathrm{SD}=1.141$ ), website foundation $($ mean $=3.23$; $\mathrm{SD}=1.257)$ has the most effects in the Uganda's steel marketing activities followed by lead generation (mean $=3.60 ; \mathrm{SD}=1.228)$, content strategy (mean = 3.74; $\mathrm{SD}=1.124)$, pipeline management $($ mean $=3.75 ; \mathrm{SD}=1.071)$, and data analysis $($ mean $=3.81 ; \mathrm{SD}=1.192)$. However, respondents also agreed that 
emerging online channels (mean $=4.20 ; \mathrm{SD}=1.128$ ), the omnichannel are the cause of downwards price pressure on traditional channels. Meanwhile, there is undeniable effects on positioning (mean $=4.20$; $\mathrm{SD}=0.934$ ), although respondents argued that companies still are able to use old traditional methods to perfection, otherwise there is already a big call for advanced technology to allow them compete favorably in the markets.

\subsubsection{Correlation Results}

The research thought to examine the relationship between the cost of doing business and variables; 1) increased supply chain complexity, 2) value addition, 3) rapidly evolving technological capabilities, 4) organizational realignments to integrate physical and digital technologies, 5) product quality, quantity, and raw material, 6) skills gap, research and innovation, 7) positioning in the market, 8) website foundation, 9) Technology stack, 10) content strategy, 11) lead generation, 12) Pipeline management 13) Channel strategy, 14) data analysis (analytic tools), 15) illicit trade practices.

In a bid to address these objectives, Pearson's correlation was used and the findings are indicated in Table 4 below.

- Strong relationship between cost of doing business and variables; (1), (3), (5), and (13)

The results from Table 5 shows the correlation between variables, where there was a strong positive correlation between items 3,5 , and 13 at $(\mathrm{r}(89)=0.558$, $0.582,0.518$, Mean $=4.43,4.31,4.20,4.23, \mathrm{SD}=0.956,1.029,1.128), P<0.01)$ explaining $97.1 \%$ of the variations. This implied that there were statistical evidence to explain that rapidly evolving technological capabilities, product quality, quantity, and raw material, and channel strategy have strong relationship with the cost of doing business.

- Moderate relationship between cost of doing business and variables; (2), (4), (7), (12), and (15)

The results from Table 5 shows a moderate positive correlation between items $2,4,7,12$ and 15 at $(\mathrm{r}(89)=0.476,0.467,0.450,0.442,0.422$, Mean $=4.41,4.47$, $4.20,3.75,4.26, \mathrm{SD}=0.977,0.993,0.934,1.071,0.941, P<0.01)$ explaining $97.1 \%$ of the variations. This indicated that there were statistical evidence to explain that value addition, organizational realignments to integrate physical and digital technologies, positioning in the market, pipeline management, and illicit trade practices have moderate relationship with the cost of doing business.

- Weak relationship between cost of doing business and variables; (6), (8), (9), (10), (11), and (14)

The results from Table 5 show a weak positive correlation between items 6,8 , $9,10,11$, and 14 at $(\mathrm{r}(89)=0.275,0.09,0.109,0.250,0.241,0.258$, Mean $=4.12$, $3.23,3.02,3.74,3.60,3.81, \mathrm{SD}=1.073,1.257,1.141,1.124,1.228,1.192, P<0.05)$, explaining $97.1 \%$ of the variations. This implied that there were statistical evidence to explain that skills gap, research and innovation, positioning in the 
A. O. Komakech et al.

Table 4. The relationship between variables.

\section{Pearson Correlations}

\begin{tabular}{|c|c|c|c|c|c|c|c|c|c|c|c|c|c|c|c|c|}
\hline Variables & (1) & (2) & (3) & (4) & (5) & (6) & (7) & (8) & (9) & (10) & (11) & (12) & (13) & (14) & (15) & (16) \\
\hline $\begin{array}{c}\text { Increased } \\
\text { supply chain } \\
\text { complexity (1) }\end{array}$ & 1 & & & & & & & & & & & & & & & \\
\hline $\begin{array}{c}\text { Value } \\
\text { addition (2) }\end{array}$ & $0.476^{* *}$ & 1 & & & & & & & & & & & & & & \\
\hline $\begin{array}{c}\text { Rapidly evolving } \\
\text { technological } \\
\text { capabilities (3) }\end{array}$ & $0.558^{* *}$ & $0.430^{* *}$ & 1 & & & & & & & & & & & & & \\
\hline $\begin{array}{l}\text { Organizational } \\
\text { realignments (4) }\end{array}$ & $0.467^{* *}$ & $0.510^{\star *}$ & $0.756^{* *}$ & 1 & & & & & & & & & & & & \\
\hline $\begin{array}{c}\text { Quality, } \\
\text { quantity \& raw } \\
\text { material (5) }\end{array}$ & $0.582^{* *}$ & $0.382^{* *}$ & $553^{* *}$ & $0.628^{\star *}$ & 1 & & & & & & & & & & & \\
\hline $\begin{array}{c}\text { Skills gap, } \\
\text { research \& } \\
\text { innovation }(6)\end{array}$ & $0.275^{* *}$ & $0.451^{\star *}$ & $0.350^{* *}$ & $0.384^{* *} c$ & $0.298^{\star *}$ & 1 & & & & & & & & & & \\
\hline Positioning (7) & $0.450^{* *}$ & $0.422^{\star *}$ & $0.576^{* *}$ & $0.569^{* *} c$ & $0.433^{* *}$ & $0.553^{* *}$ & 1 & & & & & & & & & \\
\hline $\begin{array}{c}\text { Website } \\
\text { foundation (8) }\end{array}$ & 0.09 & 0.167 & $0.222^{*}$ & $0.295^{\star *}$ & 0.133 & $0.276^{\star *}$ & $0.321^{\star \star}$ & 1 & & & & & & & & \\
\hline $\begin{array}{l}\text { Technology } \\
\text { stack (9) }\end{array}$ & 0.109 & 0.183 & 0.166 & 0.139 & -0.006 & $0.240^{*}$ & $0.333^{* *}$ & $0.622^{\star *}$ & 1 & & & & & & & \\
\hline $\begin{array}{c}\text { Content } \\
\text { strategy (10) }\end{array}$ & $0.250^{*}$ & $0.392^{\star *}$ & $0.355^{\star *}$ & $0.352^{* *}$ & $0.253^{*}$ & $0.377^{\star *}$ & $0.410^{\star *}$ & $0.508^{\star *}$ & ${ }^{*} 0.552^{\star *}$ & 1 & & & & & & \\
\hline $\begin{array}{c}\text { Lead } \\
\text { generation (11) }\end{array}$ & $0.241^{\star}$ & 0.191 & $0.449^{* *}$ & $0.365^{\star *} \mathrm{c}$ & $0.308^{\star *}$ & $0.365^{\star *}$ & $0.437^{\star *}$ & $0.413^{* *}$ & ${ }^{*} 0.472^{\star *}$ & $0.543^{\star *}$ & 1 & & & & & \\
\hline $\begin{array}{c}\text { Pipeline } \\
\text { management } \\
(12)\end{array}$ & $0.442^{* *}$ & $0.248^{*}$ & $0.378^{* *}$ & $0.385^{\star *} \mathrm{C}$ & $0.313^{* *}$ & $0.385^{\star *}$ & $0.551^{\star *}$ & $0.374^{\star *}$ & ${ }^{*} 0.441^{* *}$ & $0.590^{\star *}$ & $0.557^{\star *}$ & 1 & & & & \\
\hline $\begin{array}{c}\text { Channel } \\
\text { strategy (13) }\end{array}$ & $0.518^{* *}$ & $0.400^{* *}$ & $0.549^{\star *}$ & $0.571^{\star *} \mathrm{C}$ & $0.512^{* *}$ & $0.311^{\star *}$ & $0.448^{\star *}$ & $0.218^{*}$ & * 0.206 & $0.410^{\star *}$ & $0.450^{* *}$ & $0.557^{\star \star}$ & 1 & & & \\
\hline $\begin{array}{c}\text { Data analysis } \\
\text { (analytic tools) } \\
\text { (14) }\end{array}$ & $0.258^{*}$ & $0.333^{\star *}$ & $0.315^{\star *}$ & $0.338^{\star *}$ & $0.265^{\star}$ & $0.339^{* *}$ & $0.443^{* *}$ & $0.496^{* *}$ & ${ }^{*} 0.452^{\star *}$ & $0.593^{\star *}$ & $0.374^{* *}$ & $0.633^{* *}$ & $0.425^{\star *}$ & 1 & & \\
\hline $\begin{array}{c}\text { Illicit trade } \\
\text { practices (15) }\end{array}$ & $0.422^{* *}$ & $0.378^{\star \star}$ & $0.392^{\star *}$ & $0.353^{\star *} c$ & $0.328^{\star *}$ & $0.386^{\star *}$ & $0.395^{* *}$ & 0.183 & $0.295^{* *}$ & $0.298^{\star *}$ & $0.274^{* *}$ & $0.431^{\star \star}$ & $0.411^{\star *}$ & $0.381^{* *}$ & 1 & \\
\hline $\begin{array}{l}\text { Cost of doing } \\
\text { business (16) }\end{array}$ & $0.502^{\star *}$ & $0.534^{\star \star}$ & $0.360^{* *}$ & $0.338^{\star *} c$ & $0.448^{\star *}$ & 0.203 & $0.281^{\star *}$ & 0.025 & -0.022 & 0.095 & 0.085 & 0.183 & $0.259^{*}$ & 0.144 & $0.253^{*}$ & 1 \\
\hline
\end{tabular}

${ }^{*}$ Correlation is significant at the 0.01 level (2-tailed). ${ }^{*}$ Correlation is significant at the 0.05 level (2-tailed). Source: Primary data.

market, website foundation, technology stack, content strategy, lead generation, pipeline management, channel strategy, and data analysis (analytic tools) have weak relationship with the cost of doing business. 
Table 5. Regression analysis.

\begin{tabular}{|c|c|c|c|c|c|c|}
\hline & \multirow{2}{*}{ Model } & \multicolumn{2}{|c|}{$\begin{array}{l}\text { Unstandardized } \\
\text { Coefficients }\end{array}$} & \multirow{2}{*}{$\begin{array}{c}\begin{array}{c}\text { Standardized } \\
\text { Coefficients }\end{array} \\
\text { Beta }\end{array}$} & \multirow{2}{*}{$\mathrm{t}$} & \multirow{2}{*}{ Sig. } \\
\hline & & B & $\begin{array}{l}\text { Std. } \\
\text { Error }\end{array}$ & & & \\
\hline \multirow{16}{*}{1} & (Constant) & 0.004 & 0.088 & & 0.040 & 0.968 \\
\hline & Increased supply chain complexity & 0.194 & 0.134 & 0.194 & 1.446 & 0.152 \\
\hline & Value addition & 0.498 & 0.124 & 0.499 & 4.023 & 0.000 \\
\hline & $\begin{array}{c}\text { Rapidly evolving } \\
\text { technological capabilities }\end{array}$ & 0.132 & 0.156 & 0.132 & 0.847 & 0.400 \\
\hline & Organizational realignments & -0.149 & 0.162 & -0.149 & -0.916 & 0.362 \\
\hline & $\begin{array}{l}\text { Product quality, quantity \& } \\
\text { raw material }\end{array}$ & 0.266 & 0.131 & 0.266 & 2.028 & 0.046 \\
\hline & Skills gap, research \& innovation & -0.076 & 0.118 & -0.074 & -0.640 & 0.524 \\
\hline & Positioning & 0.008 & 0.138 & 0.008 & 0.059 & 0.953 \\
\hline & Website foundation & 0.041 & 0.127 & 0.041 & 0.324 & 0.747 \\
\hline & Technology stack & -0.049 & 0.137 & -0.049 & -0.359 & 0.720 \\
\hline & Content strategy & -0.178 & 0.136 & -0.176 & -1.314 & 0.193 \\
\hline & Lead generation & -0.033 & 0.130 & -0.032 & -0.254 & 0.800 \\
\hline & Pipeline management & 0.135 & 0.153 & 0.133 & 0.884 & 0.380 \\
\hline & Channel strategy & -0.116 & 0.128 & -0.115 & -0.903 & 0.369 \\
\hline & Data analysis (analytic tools) & -0.027 & 0.131 & -0.027 & -0.208 & 0.836 \\
\hline & Illicit trade practices & -0.018 & 0.116 & -0.018 & -0.157 & 0.876 \\
\hline \multicolumn{7}{|c|}{ Dependent variable: Cost of doing business, Source: Primary data. } \\
\hline & $\mathbf{R}$ & & & 0.656 & & \\
\hline & R Square & & & 0.430 & & \\
\hline & Adjusted R Square & & & 0.315 & & \\
\hline & F Statistic & & & 3.722 & & \\
\hline & Sig. & & & 0.000 & & \\
\hline
\end{tabular}

Predictors: (Constant): Illicit trade practices, Data analysis (analytic tools), Channel strategy, Pipeline management, Lead generation, Content strategy, Technology stack, Website foundation, Positioning, Skills gap, research \& innovation, Product quality, quantity \& raw material, Organizational realignments, Rapidly evolving technological capabilities, Value addition, Increased supply chain complexity. Dependent Variable: Cost of doing business.

\subsubsection{Regression Results}

The study analyzed the effect of industry 4.0 on marketing activities of iron and steel industry in relation to the cost of doing business basing on multiple simple regression analysis. The analysis results are shown in Table 5 above.

The regression results in Table 5, above showed that the $\mathrm{R}^{2}$ value was 0.430 hence $43 \%$ of the variation in the cost of doing business was explained by the variations in illicit trade practices, data analysis (analytic tools), channel strategy, 
pipeline management, lead generation, content strategy, technology stack, website foundation, positioning, skills gap, research \& innovation, product quality, quantity \& raw material, organizational realignments, rapidly evolving technological capabilities, value addition, and increased supply chain complexity. Furthermore, results indicated a significant model $(F=3.722$, sig $=0.000)$ to explain a multi regression equation of cost of doing business:

The regression equation with more than one term:

$$
y=d_{0}+d_{1} x_{1}+d_{2} x_{2}+\cdots+d_{k} x_{k}
$$

where:

- $y$ is the response variable

- $d_{0}$ is the constant

- $d_{1}, d_{2}, \cdots, d_{k}$ are the coefficients

- $x_{1}, x_{2}, \cdots, x_{k}$ are the values of the term

$$
\begin{aligned}
Y= & 0.004+0.194 x_{1}+0.498 x_{2}+0.132 x_{3}-0.149 x_{4}+0.266 x_{5} \\
& -0.076 x_{6}+0.008 x_{7}+0.041 x_{8}-0.049 x_{9}-0.178 x_{10} \\
& -0.033 x_{11}+0.135 x_{12}-0.116 x_{13}-0.027 x_{14}-0.018 x_{15}
\end{aligned}
$$

The fifteen predictors cause $43 \%$ variations in the cost of doing business at a coefficient of multiple determination $(\mathrm{R}$ Square $=0.430$ ). Thus, the regression output ( $\mathrm{R}=0.656$ ) suggests if industry 4.0 transformation are well managed, it would significantly impact positively on the cost of doing business in Uganda's iron and steel industry and other developing countries in Africa. It was also established that value addition was the most likely contributor to industry $4.0 \mathrm{im}$ pact on the cost of doing business represented by the highest coefficient of $(\mathrm{B}=$ 0.498) as compared to others. In addition, it was observed that illicit trade practices was the most negative contributors to the cost of doing business $(\mathrm{B}=$ -0.018 ). This implied that enhancement of regulatory mechanisms to remove incentives for illicit trade practices will result in percentage change to -0.018 reduction in cost of doing business.

\subsubsection{Possible Solutions as Suggested by Respondents}

In a bid to find possible solutions to the impacts of industry 4.0 on marketing activities of iron and steel industry and the rising cost of doing business in African developing countries, participants were provided with free space or opportunity to suggest possible solutions (questionnaire 8 ). The results were as tabulated in a pie chart below.

Results in Figure 7, shows infrastructure development and internet access, investment in information technology, capacity building and research, got the highest percentage approval. However, respondents agreed that policies formed in consultation with the industry, enhanced mechanism to control illicit trade practices and improvement in both local and foreign investment policies would have significant effects. The lowest agreement percentage is for improvement of Uganda capacity to use information for development and also supports the likelihood of fearing to expose illicit practices in trade. These results point the fact 


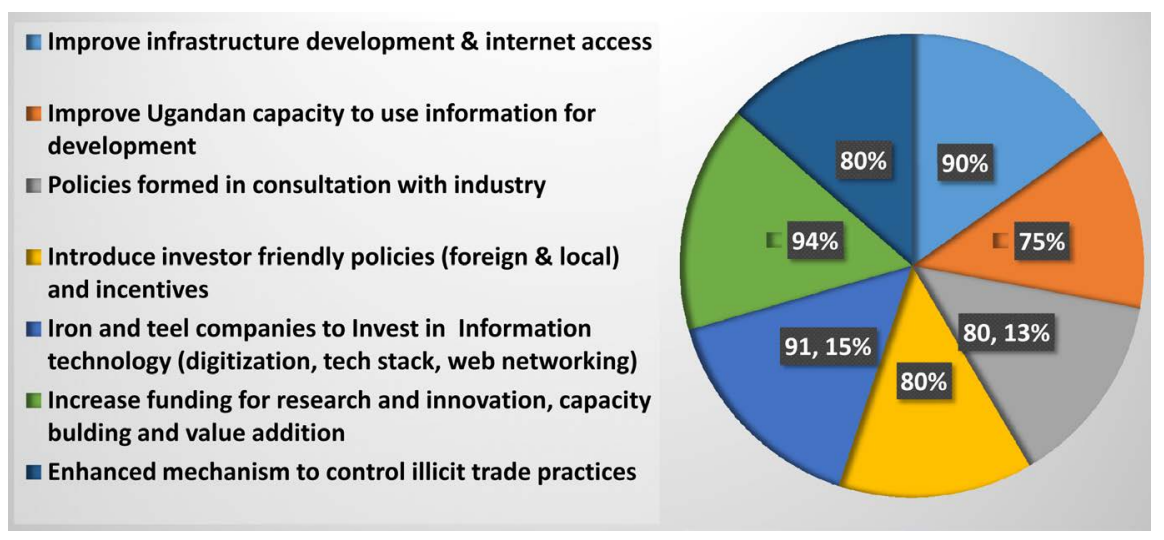

Figure 7. To what extend each of these solutions would help to address the impact of industry 4.0 transformation challenges in the Uganda iron and steel industrial market. Source: Primary data.

that Uganda government ability to use social media for educational, political, and social campaigns such as immunization for all children below six years, youths to abstain from sex before marriage, or girls child education.

\subsection{Discussions}

For most of the steel producing companies their main aim is to keep production costs as low as possible by balancing manufacturing expenses to fend off competitions, and focus on marketing activities and strategies that engage with customer to build strong relationships with them (Verhoef et al., 2010). Industry 4.0 transformation has brought in new technologies with the aim of integrating objects, people and machines across organizational boundaries to form a new type of networked value chain. Therefore, this study used statistical evidence to identify which consideration factors are relevant when adopting industry 4,0 in relation to the cost of doing business in developing countries such as: evolving technological capabilities, product quality, quantity, and raw material, channel strategy, increased supply chain complexity, value addition, organizational realignments, positioning, pipeline management, illicit trade practices, skills gap, research and innovation, positioning, website foundation, technology stack, content strategy, lead generation, pipeline management, channel strategy, and data analysis. Then, make comparison between descriptive statistics and possible solutions as suggested by respondents in questionnaire 8 .

1) Strong relationship between cost of doing business and rapidly evolving technological capabilities, product quality, quantity, and raw material, channel strategy and increased supply chain complexity.

The findings revealed that rapidly evolving technological capabilities, product quality, quantity, and raw material, and channel strategy $(\mathrm{r}(89)=0.558,0.582$, 0.518 , Mean $=4.43,4.31,4.20,4.23, \mathrm{SD}=0.956,1.029,1.128), P<0.01)$ have strong positive relationship to the cost of doing business. This implied that there is statistical evidence to conclude that any effort taken to adopt industry 4.0 would have strong positive impact to the cost of doing business in relation to ra- 
pidly evolving technological capabilities, product quality, quantity, and raw material, and channel strategy. Meanwhile, increased supply chain complexity $(\mathrm{r}=$ 0.502 and $P>0.01)$ has strong positive but normal relationship to the cost of doing business.

2) Moderate relationship between cost of doing business and value addition, organizational realignments, positioning, pipeline management, and illicit trade practices.

The findings revealed that value addition, organizational realignments, positioning, pipeline management, and illicit trade practices $(\mathrm{r}(89)=0.476,0.467$, $0.450,0.442,0.422$, Mean $=4.41,4.47,4.20,3.75,4.26, \mathrm{SD}=0.977,0.993,0.934$, 1.071, 0.941, $P<0.01$ ) have moderate positive relationship to the cost of doing business. This implied that there is statistical evidence to conclude that any effort taken to implement industry 4.0 would have moderate significant impact to the cost of doing business in relation to value addition, organizational realignments, positioning, pipeline management, and illicit trade practices.

3) Weak relationship between cost of doing business and skills gap, research and innovation, positioning, website foundation, technology stack, content strategy, lead generation, pipeline management, channel strategy, and data analysis.

The findings revealed that skills gap, research and innovation, positioning, website foundation, technology stack, content strategy, lead generation, pipeline management, channel strategy, and data analysis $(\mathrm{r}(89)=0.275,0.09,0.109$, $0.250,0.241,0.258$, Mean $=4.12,3.23,3.02,3.74,3.60,3.81, \mathrm{SD}=1.073,1.257$, $1.141,1.124,1.228,1.192, P<0.05)$ have weak direct relationship to the cost of doing business.

4) Descriptive statistics and possible solutions as suggested by respondents are compared.

Results in Figure 7, and descriptive statistics results in Table 3 are in agreement. That is, Infrastructure development and internet access, investment in information technology, skills, innovation, research, and value addition and investment in new technologies are among the highest percentage approval. This confirms the problems facing African iron and steel industry and possible solutions to be considered.

\subsection{The Study Recommendations}

- Change from brochure-ware to modern marketing due to rapidly evolving technological capabilities: B2B buying has moved online, many steel manufacturing marketing departments still rely on a basic website and trade shows to generate leads. That is, if industry 4.0 transformation are well managed, it would significantly impact positively on the cost of doing business. Many iron and steel companies in Africa are still missing out on the value digital marketing can bring on board. The modern manufacturing marketing department is connected, optimized, transparent, and agile. It can help manufacturers understand what buyers are doing at every stage of the funnel and 
engage them with the right information.

- Change sales channels: with this new connected paradigm, manufacturers are considering taking more business direct. If you sell through indirect channels, your traditional sales channels may not be ready or want to move into Industry 4.0 technologies. There is a significant challenge to educate a reluctant sales channel about a paradigm that promises to transform the entire industry. Therefore, steel manufacturers should access the readiness of their sales channel for IoT-based solutions, adjust their sales and marketing resources accordingly, and keep nurturing leads.

- Expand content: by introducing more roles in the buying process means you need more content to educate the targeted the new audience. Your traditional audience will also need more content. In addition to capabilities, increased productivity and cost efficiencies. Thus, design engineers need to understand how the data produced can be used for decision-making and how IoT works.

- New buyers, new target audiences: smart products are engineered for a connected environment won't be adopted without IT buy-in and support. Because of this, involve IT directors and managers, steel manufacturers need to market to this new audience. In addition to traditional, design engineers need to learn more about these new roles by interviewing people in these roles and creating personas a fictional representation of each role that includes customer demographics, behavior patterns, motivations, challenges, and goals.

- Increased direct contact with end customers: In this industry 4.0 era, end customers are directly connected to manufacturers early in the buying process. This helps manufacturers learn directly from customers rather than relying on a middleman. New insights bring new opportunities for revenue streams. Connected technologies and products enable for revenue opportunities after the initial sale that were not readily available before. Unlike traditional sales where sales teams interacted with customers up until the point of sale, IoT actually lengthens the relationship by providing constant connectivity and leveraging it.

\subsection{Limitations}

Although the research results are expected to make a great contribution to the body of knowledge in the area of industry 4.0 impact on marketing activities, there are some limitations to their application. As the limitation of questionnaires, they were restricted by time and respondents' attitudes and Covid-19 pandemic. Some respondents tended to hide information to make them feel safer. This could be more evident. However, the researchers assured them that data could only be used for research purposes and be treated with the utmost confidentially. This motivated respondents to provide more detailed information. Some respondents could miss the objectivity of the questions and tended to provide wrong answers which made it more difficult to gain more useful information. However, respondents were encouraged to carefully respond to all items as 
the information could be used to improve their company's sales and marketing performance and probably their remuneration.

However, One could argue that the impact of industry 4.0 technologies and the emergence of internet technology and online marketing that has created downwards price pressure on traditional channels if adopted or prioritized by companies can be used as competitive advantage. In addition, the ability of cyber-physical systems, people, and all smart factory components to communicate with each other through the IoT and internet technology can be considered as simple enhancements of technology-enabled processes that has been lacking in the Uganda iron and steel industrial marketing activities (Libai et al., 2020). But, lack of personnel with skills and technical know-how and capabilities amid infrastructure development and internet access since 75\% of Ugandan's population live in rural areas. Companies also lack of financial resources to implement the industry 4.0 projects.

\subsection{Conclusion}

As the result of dramatic change Industry 4.0 technological developments brings, the Uganda iron and steel companies need to adopt new or improved technologies in marketing activities. Manufacturers must perceive the positive effects because it has significant effects on end-products prices, quality and services as well as the need to open new sales distribution channels. Hence, its potential value before starting the process. In this context, address the key implications of this necessary transition including the development of the technology, customization of steel products, and solving channels deficiency. Hence, rise to customer power by use of information technology for digital optimization. Thus, steel producers should aim at creating opportunities in emerging markets, skills development, resource management, and publicity or marketing capabilities by focusing on two key areas, including:

- Operation transformation: 1) to improve on productivity such maximising asset utilisation and minimising downtime, direct and indirect labour efficiency, reducing supply chain costs and synchronisation, accuracy in schedule and planning stability; 2) Risk reduction to ensure raw materials price and availability, manage warranty and effectively mitigate geographic risks.

- Business growth: 1 ) incremental revenue to identify growth sources for core business, grow after-market revenue streams, deepen customer understanding and insights, and strengthen customer integration and channels; 2) new revenue to create new products and services, expand internationally and in emerging markets, and identify attractive merger and acquisition opportunities.

- Government to introduce investors friendly policies/incentives, improve on infrastructure development and financial support to industrial research institutes, and enhance regulatory mechanisms to remove incentives for illicit trade. For instance, if there is no incentive in illicit trade then the propensity to use information technology in the market place will improve. However, 
this research recommends further research in this dimension and in the area of sales performance.

\section{Acknowledgements}

The authors would like to acknowledge the following companies for taking the lead and providing core supports during research periods: Roofings Group (Roofings Rolling Mills Ltd, and Roofings Ltd.) who took lead roles during survey processes, Uganda Iron and Steel Manufacturers Association and Uganda Manufacturers Association who took lead roles in checking reliability and validity of the research questions and reviewing of the manuscript.

\section{Conflicts of Interest}

The authors declare no conflicts of interest regarding the publication of this paper.

\section{References}

Adetayo, J. O., Sanni, S. A., \& Ilori, M. O. (1999). The Impact of Information Technology on Product Marketing: A Case Study of a Multinational Company in Nigeria. Technovation, 19, 691-699. https://doi.org/10.1016/S0166-4972(99)00051-6

Allahverdi, A., \& Gupta, J., \& Aldowaisan, T. (1999). A Review of Scheduling Research Involving Setup Considerations. Omega, 27, 219-239. https://doi.org/10.1016/S0305-0483(98)00042-5

Almada-Lobo, F. (2016). The Industry 4.0 Revolution and the Future of Manufacturing Execution Systems (MES). Journal of Innovation Management, 3, 16-21. https://doi.org/10.24840/2183-0606_003.004_0003

Anderl, R. (2014). Industrie 4.0-Advanced Engineering of Smart Products and Smart Production. 19th International Seminar on High Technology, Technological Innovations in the Product Development, Piracicaba, Brazil, 9 October 2014, 1-14.

Arca, J. G., Garrido, A. T. G. P., Prado, J. C. P., \& Sacaluga, A. M. M. (2011). Sostenibilidady mejora logstica: Un caso prctico. XV Congreso deIngeniera de Organizacion, Cartagena, 7-9 Septiembre 2011, 712-721.

Arcelormittal/SQLI Digital Experience (2016). https://sqli.be/Homepage-Belgium/News/Press-releases/Arcelormittal-Downstream-So lutions-launches-its-first-e-commerce-web-shop

Baygin, M., Yetis, H., Karakose, M., \& Akin, E. (2016, September). An Effect Analysis of Industry 4.0 to Higher Education. 2016 15th International Conference on Information Technology Based Higher Education and Training (IT-HET), Istanbul, 8-10 September 2016, 1-4. https://doi.org/10.1109/ITHET.2016.7760744

Bennett, S. (2013). 45 Amazing Social Media Facts, Figures \& Statistics. http://www.mediabistro.com/alltwitter/45-social-media-stats_b49582

Booms, B. H., \& Bitner, M. J. (1981). Marketing Strategies and Organization Structures for Service Firms. In J. H. Donnelly, \& W. R. George (Eds.), Marketing of Services (pp. 47-51). Chicago, IL: American Marketing Association.

Buhalis, D., \& Law, R. (2008). Progress in Information Technology and Tourism Management: 20 Years on and 10 Years after the Internet. The State of eTourism Research. Tourism Management, 29, 609-623. 
https://doi.org/10.1016/j.tourman.2008.01.005

Buttle, F. (1989). The Social Construction of Needs. Psychology and Marketing, 6, 197-210. https://doi.org/10.1002/mar.4220060304

Chen, P. T., \& Hsieh, H. P. (2012). Personalized Mobile Advertising: Its Key Attributes, Trends, and Social Impact. Technologic Forecasting and Social Change, 79, 543-557. https://doi.org/10.1016/j.techfore.2011.08.011

Clemons, E. K., Wilson, J., Matt, C., Hess, T., Ren, F., Jin, F. et al. (2016). Global Differences in Online Shopping Behavior: Understanding Factors Leading to Trust. Journal of Management Information System, 33, 1117-1148. https://doi.org/10.1080/07421222.2016.1267531

Closs, D. J., \& Xu, K. (2000). Logistics Information Technology Practice in Manufacturing and Merchandising Firms. International Journal of Physical Distribution and Logistics Management, 30, 869-886. https://doi.org/10.1108/09600030010351264

Deutsche Welle (2019). https://www.dw.com/en/online-shopping-in-africa-somewhere-between-smartphonesand-paper-catalogues/a-51662266

Dombrowski, U., \& Wagner, T. (2014). Mental Strain as Field of Action in the 4th Industrial Revolution. Procedia CIRP, 17, 100-105. https://doi.org/10.1016/j.procir.2014.01.077

Drath, R., \& Horch, A. (2014). Industrie 4.0: Hit or Hype? IEEE Industrial Electronics Magazine, 8, 56-58. https://doi.org/10.1109/MIE.2014.2312079

Facebook.com Internal Statistics (2019). https://newsroom.fb.com/company-info/

Ferrel, O. C., Hartline, M. D., \& Lucas Jr., G. H. (2002). Marketing Strategy (2nd ed., p. 74). Bangalore: Thomson southwestern.

Fleisher, C. S. (2008). Using Open Source Data in Developing Competitive and Marketing Intelligence. European Journal of Marketing, 42, 852-866. https://doi.org/10.1108/03090560810877196

Hermann, M., Pentek, T., \& Otto, B. (2016). Design Principles for Industrie 4.0 Scenarios. 2016 49th Hawaii International Conference on System Sciences (HICSS), Koloa, HI, 10 March 2016, 3928-3937. https://doi.org/10.1109/HICSS.2016.488

Hood, J., \& Brady, A. (2016). Industry 4.0 Engages Customers: The Digital Manufacturing Enterprise Powers the Customer Life Cycle. New York: Deloitte University Press.

İnal, M. E. (2009). Müşteri Analizi in Pazarlama Stratejileri Yönetsel Bir Yaklaşım. In Ö. Torlak, \& R. Altunışık (Eds.), Müşteri Analizi in Pazarlama Stratejileri Yönetsel Bir Yaklaşım, $\ddot{O}$ (pp. 107-136). İstanbul: Beta Basım Yayım A.Ş.

Jayaram, D., Manrai, A. K., \& Manrai, L. A. (2015). Effective Use of Marketing Technology in Eastern Europe: Web Analytics, Social Media, Customer Analytics, Digital Campaigns and Mobile Applications. Journal of Economics, Finance and Administrative Science, 20, 118-132. https://doi.org/10.1016/j.jefas.2015.07.001

Kenyanz.com (2021). Multi Geo Business \& Pros Directory. https://www.kenyanz.com/uganda/kampala/manufacturing-industry/uganda-baati-ltd

Kopetz, H. (2011). Internet of Things. In Real-Time Systems (pp. 307-323). Boston, MA: Springer. https://doi.org/10.1007/978-1-4419-8237-7_13

Kotler, P. (2012). Soru ve Cevaplarla Günümüzde Pazarlamanın Temelleri (Çev. Ümit Şensoy) (3. Bas-kı). İstanbul: Optimist Yayınları.

Kotler, P., \& Keller K. L. (2006). Marketing Management (5th ed.). Bucharest: Teora Publishing House. 
Kotler, P., Kartajaya, H., \& Setiawan, I. (2010). Marketing 3.0: From Products to Customers to the Human Spirit. Hoboken, NJ: John Wiley Sons. https://doi.org/10.1002/9781118257883

Kotler, P., Kartajaya, H., \& Setiawan, I. (2017). Marketing 4.0-Moving from Traditional to Digital. Hoboken, NJ: John Wiley and Sons.

Kwihangana, S. (6 August 2014). Roofings Group Looks to Open Manufacturing Plant in Rwanda. New Times (Rwanda), Kigali. https://www.newtimes.co.rw/section/read/77428

Lasi, H., Fettke, P., Kemper, H. G., Feld, T., \& Hoffmann, M. (2014). Industry 4.0. Business Information Systems Engineering, 6, 239-242. https://doi.org/10.1007/s12599-014-0334-4

Lee, F. K., \& Turban, D. B. (2010). Natural Rewards Self-Management, Personality and Achievement Outcome. Journal of Applied Social Psychology, 40, 2267-2294. https://doi.org/10.1111/j.1559-1816.2010.00660.x

Li, K., \& Du, T. C. (2012). Building a Targeted Mobile Advertising System for Location-Based Services. Decision Support System, 54, 1-8. https://doi.org/10.1016/j.dss.2012.02.002

Libai, B., Bart, Y., Gensler, S., Hofacker, C., Kaplan, A., \& Kötterheinrich, K. (2020). Brave New World? On AI and the Management of Customer Relationships. Journal of Interactive Marketing, 51, 44-56. https://doi.org/10.1016/j.intmar.2020.04.002

Likert, R. A. (1932). Technique for the Measurement of Attitudes. New York: Archives of Psychology.

Longo, F., Nicoletti, L., \& Padovano, A. (2017). Smart Operators in Industry 4.0: A Human-Centered Approach to Enhance Operators' Capabilities and Competencies within the New Smart Factory Context. Computers \& Industrial Engineering, 113, 144-159. https://doi.org/10.1016/j.cie.2017.09.016

Ltifi, M., \& Gharbi, J. (2015). The Effect of Logistics Performance in Retail Store on the Happiness and Satisfaction of Consumers. Procedia Economics and Finance, 23, 1347-1353. https://doi.org/10.1016/S2212-5671(15)00516-X

Moncrief, W. C., \& Cravens, D. W. (1999). Technology and Changing Marketing World. Marketing Intelligence and Planning, 17, 329-332. https://doi.org/10.1108/02634509910301142

Moreno, A., Velez, G., Ardanza, A., Barandiaran, I., de Infante, A., \& Chopitea, R. (2017). Virtualisation Process of a Sheet Metal Punching Machine within the Industry 4.0 Vision. International Journal on Interactive Design and Manufacturing, 11, 365-373. https://doi.org/10.1007/s12008-016-0319-2

Muwanguzi, A. J. B., Olowo, P., Guloba, A., \& Muvawala, J. (2018). Industrialisation as a Vehicle for Uganda to Achieve a 1st World Economy by 2040: A Review of Uganda's Industrialisation Efforts. American Journal of Industrial and Business Management, 8, 496-513. https://doi.org/10.4236/ajibm.2018.83033

Muwanguzi, A. J. B., Olowo, P., Sebukeera, H., Guloba, A., Mezulic, D., Bonci, P., \& Muvawala, J. (2020b). Modelling the Growth Trend of the Iron and Steel Industry: Case for Uganda. American Journal of Industrial and Business Management, 10, 1640-1654. https://doi.org/10.4236/ajibm.2020.109104

Muwanguzi, A. J., Sebukeera, H., Ajidiru, R., Guloba, A., Rukenzo, G., \& Muvawala, J. (2020a). The Prospects of Uganda's Iron Ore Deposits in Developing the Iron and Steel Industry. Journal of Minerals and Materials Characterization and Engineering, 8, 316-329. 
National Planning Authority (2010). National Development Plan (2010/11-2014/15). Kampala.

National Planning Authority (2015). Second National Development Plan (NDPII) 2015/16-2019/20. Kampala: National Planning Authority.

National Planning Authority (2018). Developing the Iron and Steel Industry-Harnessing the Fruits.

http://npa.go.ug/wp-content/uploads/2018/07/Iron-and-Steel-Industry-in-Uganda.pdf

Neeraja, B., Mehta, M., \& Chandani, A. (2014). Supply Chain and Logistics for the Present Day Business. Procedia Economics and Finance, 11, 665-675. https://doi.org/10.1016/S2212-5671(14)00232-9

Ngendahayo, J. C. (2019). Marketing Strategies and Sales Performance of Manufacturing Firms: A Case Study on Tembo Steel in Uganda; A Case Study on Tembo Steel in Uganda. Master Thesis, Uganda: Kyambogo University.

Obwona, M., Shinyekwa, I., Kiiza, J., \& Hisali, E. (2014). The Evolution of Industry in Uganda (pp. 1-57). Working Paper (2014/021), The World Institute for Development Economics Research. https://doi.org/10.35188/UNU-WIDER/2014/742-4

Oluyisola, O. E., Sgarbossa, F., \& Strandhagen, J. O. (2020). Smart Production Planning and Control: Concept, Use-Cases and Sustainability Implications. Sustainability, 12, 3791. https://doi.org/10.3390/su12093791

Parrott, A., \& Warshaw, L. (2017). Industry 4.0 and the Digital Twin: Manufacturing Meets Its Match. New York: Deloitte University Press.

Peattie, K., \& Peters, L. (1997). The Marketing Mix in the Third Age of Computing. Marketing Intelligence and Planning, 15, 142-150. https://doi.org/10.1108/02634509710165948

Prause, M., \& Weigand, J. (2016). Industry 4.0 and Object-Oriented Development: Incremental and Architectural Change. Journal of Technology Management \& Innovation, 11, 104-110. https://doi.org/10.4067/S0718-27242016000200010

Rafiq, M., \& Ahmed, P. K. (1995). Using the 7Ps as a Generic Marketing Mix: An Exploratory Survey of UK and European Marketing Academics. Marketing Intelligent \& Planning, 13, 4-15. https://doi.org/10.1108/02634509510097793

Reichheld, F. F., \& Sasser, W. E. (1990). Zero Defections: Quality Comes to Services. Harvard Business Review, 68, 105-111.

Rennung, F., Luminosu, C. T., \& Draghici, A. (2016). Service Provision in the Framework of Industry 4.0. Procedia Social and Behavioral Sciences, 221, 372-377. https://doi.org/10.1016/j.sbspro.2016.05.127

Rozell, E. J., Pettijohn, C. E., \& Parker, S. R. (2006). Emotional Intelligence and Dispositional Affectivity as Predictors of Performance in Sales People. Journal of Marketing Theory and Practice, 14, 113-124. https://doi.org/10.2753/MTP1069-6679140202

Rust, R. T., \& Espinoza, F. (2006). How Technology Advances Influence Business Research and Marketing Strategy. Journal of Business Research, 59, 1072-1078.

https://doi.org/10.1016/j.jbusres.2006.08.002

Sada El-Balad English (2020). https://see.news/egypt-among-worlds-fastest-growing-economies-during-pandemic/

Sari, Y., \& Kozak, M. (2005). Turizm Pazarlamasına İnternetin Etkisi: Destinasyon Web Siteleri için Bir Model Önerisi. Akdeniz İIBF Dergisi, 9, 248-271.

Saunders, M., Lewis, P., \& Thornhill, A. (2009). Research Methods for Business Students (5th ed.). Italy: Rotolito Lombarda.

See, A. (2007). American Marketing Association (AMA). 
Senfuka, C., Kirabira, J., \& Byaruhanga, J. (2011). Options for Improvement of Ugandan Iron and Steel Industry. Second International Conference on Advances in Engineering and Technology, Entebbe, 31 January-2 February 2011, 228-234.

Shafiq, S. I., Sanin, C, Szczerbicki, E., \& Toro, C. (2015). Virtual Engineering Object/Virtual Engineering Process: A Specialized form of Cyber Physical System for Industrie 4.0. Procedia Computer Science, 60, 1146-1155.

https://doi.org/10.1016/j.procs.2015.08.166

Sharma, A., \& Sheth, J. N. (2004). Web-Based Marketing: The Coming Revolution in Marketing Thought and Strategy. Journal of Business Research, 57, 696-702. https://doi.org/10.1016/S0148-2963(02)00350-8

Simonis, K., Gloy, Y. S., \& Gries, T. (2016). INDUSTRIE 4.0-Automation in Weft Knitting Technology. IOP Conference Series: Materials Science and Engineering, 141, Article ID: 012014. https://doi.org/10.1088/1757-899X/141/1/012014

Sniderman, B., Mahto, M., \& Coteleer, M. (2016). Industry 4.0 and Manufacturing Ecosystems. New York: Deloitte University Press.

http://dupress.com/articles/industry-4-0-manufacturing-ecosystems-exploring-world-c onnected-enterprises

Sokolov, B., \& Ivanov, D. (2015). Integrated Scheduling of Material Flows and Information Services in Industry 4.0 Supply Networks. IFAC-PapersOnLine, 48, 1533-1538. https://doi.org/10.1016/j.ifacol.2015.06.304

Strandhagen, J. W., Alfnes, E., Strandhagen, J. O., \& Vallandingham, L. R. (2017). The Fit of Industry 4.0 Applications in Manufacturing Logistics: A Multiple Case Study. Advances in Manufacturing, 5, 344-358. https://doi.org/10.1007/s40436-017-0200-y

Sun, C. (2012). Application of RFID Technology for Logistics on Internet of Things. AASRI Procedia, 1, 106-111. https://doi.org/10.1016/j.aasri.2012.06.019

Tassey, G. (2014). Competing in Advanced Manufacturing: The Need for Improved Growth Models and Policies. Journal of Economic Perspectives, 28, 27-48. https://doi.org/10.1257/jep.28.1.27

Tekin, M. M., \& Zerenler, A. B. (2005). Bilişim Teknolojileri Kullanımının İşletme Performansına Etkileri: Lojistik Sektöründe Bir Uygulama. Ístanbul Ticaret Üniversitesi Fen Bilimleri Dergisi, 4, 115-129.

Toro, C., Barandiaran, I., \& Posada, J. (2015). A Perspective on Knowledge Based and Intelligent Systems Implementation in Industrie 4.0. Procedia Computer Science, 60, 362-370. https://doi.org/10.1016/j.procs.2015.08.143

Trends (2015). Industry 4.0 and the US Manufacturing Renaissance. Trends E-Magazine (Audio-Tech Business Book Summaries), 4-10.

UN Report/Aficanews (2020). Africa Loses Nearly \$89bn a Year in Illicit Financial Flows Such as Tax Evasion, a United Nations Study Has Showed. https://www.africanews.com/2020/09/30/africa-losing-billions-to-illicit-cash-flows-unreport//

Verhoef, P. C., Reinartz, W. J., \& Krafft, M. (2010). Customer Engagement as a New Perspective in Customer Management. Journal of Service Research, 13, 247-252. https://doi.org/10.1177/1094670510375461

Volker, S. (2005). The Impact of Technology on Marketing Strategy. Munich: GRIN Verlag. https://www.grin.com/document/38123

Waters, D. (2003). Logistics: An Introduction to Supply Chain Management. London: Palgrave Macmillan.

Witkowski, K. (2017). Internet of Things, Big Data, Industry 4.0-Innovative Solutions in 
Logistics and Supply Chains Management. Procedia Engineering, 182, 763-769. https://doi.org/10.1016/j.proeng.2017.03.197

Yannopoulos, P. (2011). Impact of the Internet on Marketing Strategy Formulation. International Journal of Business and Social Science, 2, 1-7.

Zhang, D., Ning, H., Xu, K. S., Lin, F., \& Yang, L. T. (2012). Internet of Things. Journal of Universal Computer Science, 18, 1069-1071. 